\title{
Review
}

Valérie Stiger-Pouvreau* and Mayalen Zubia

\section{Macroalgal diversity for sustainable biotechnological development in French tropical overseas territories}

https://doi.org/10.1515/bot-2019-0032

Received 12 May, 2019; accepted 17 December, 2019; online first 23 January, 2020

\begin{abstract}
This review focuses on the diversity of French tropical overseas macroalgae and their biotechnological applications. After listing the specific diversity, i.e. 641 species in French Antilles in the Atlantic Ocean, 560 species in the Indian Ocean, and 1015 species in the South Pacific Ocean, we present the potential of their metabolites and their main uses. Among the great diversity of metabolites, we focus on carbohydrates, proteins, lipids, pigments and secondary metabolites, in particular terpenes and phenolic compounds. The main applications of reef macroalgae are described in human and animal consumptions, phycocolloids extraction, production of active ingredients for health, cosmetics, agriculture, and bioremediation. For each application, we list what has been done, or will be done in French tropical overseas territories and point out the challenges faced when using this chemo-diversity, and problems linked to their exploitation. Finally, we discuss challenges to develop seaweed farming, their uses in carbon sequestration and resilience to global change, their uses for alternative proteins together with the production of bioenergy and biomaterials. As a conclusion, we encourage the research on the chemo-diversity of French reef macroalgae for industrial applications as these organisms represent a reservoir of active ingredients that is still insufficiently explored.
\end{abstract}

Keywords: biotechnological applications; coral reef; diversity; French territories; seaweeds.

*Corresponding author: Valérie Stiger-Pouvreau, Université de Bretagne Occidentale (UBO), CNRS, IRD, Ifremer, UMR-LEMAR, IUEM, rue Dumont d’Urville, 29280 Plouzané, France, e-mail: valerie. stiger@univ-brest.fr

Mayalen Zubia: University of French Polynesia, UMR-EIO, BP6570, 98702 Faa'a, Tahiti, French Polynesia

\section{Introduction}

Macroalgae are key members of marine ecosystems that provide ecological functions and further ecosystem services. Currently, 11,017 species of macroalgae are known on our planet, divided into 1901 Ulvophyceae (green algae), 7083 red algae, and 2033 Phaeophyceae (brown algae) (Guiry and Guiry 2019). These numerous species are distributed in polar, temperate and tropical areas. In this review, we present the diversity and the uses of tropical macroalgae living in coral reefs, commonly known as reef macroalgae, growing in French overseas territories. Algae present in the mangrove and brackish ecosystems are not taken into consideration. France, including its overseas territories (Figure 1), is the only country with coral reefs represented in the three oceans of the world (Gardes and Salvat 2008). The reefs and their lagoons cover more than $55,000 \mathrm{~km}^{2}$, on average twice the area of the surrounding land (Andréfouët 2008). French territories obtained the fourth world ranking for countries with coral reefs, as they are home to $10 \%$ of the world's coral reefs (Andréfouët 2008), spread over many overseas communities whose local economies depend heavily on this ecosystem. Those French overseas territories surrounded by coral reefs are presented on Figure 1 and are as follows: (1) in the Atlantic Ocean: Guyana, Martinique, Guadeloupe, Marie-Galante, the Saintes, Désirade, SaintBarthélemy and Saint-Martin; (2) in the Indian Ocean: Reunion Island, Mayotte and the Scattered Islands; and (3) in the Pacific Ocean: New Caledonia, French Polynesia, Wallis and Futuna and Clipperton. Since this covers Atlantic, Indian and Pacific oceans, these islands offer an exceptional diversity to explore (Gardes and Salvat 2008); it also invests France with an international responsibility in the area of conservation. Moreover, 95\% of French coral reefs are located in the Pacific Ocean (French Polynesia, New Caledonia, Wallis \& Futuna, Clipperton), with those from New Caledonia declared as a World Heritage Site in 1998, and also endowed with the largest lagoon in the world. For France, this is a worldwide recognition 


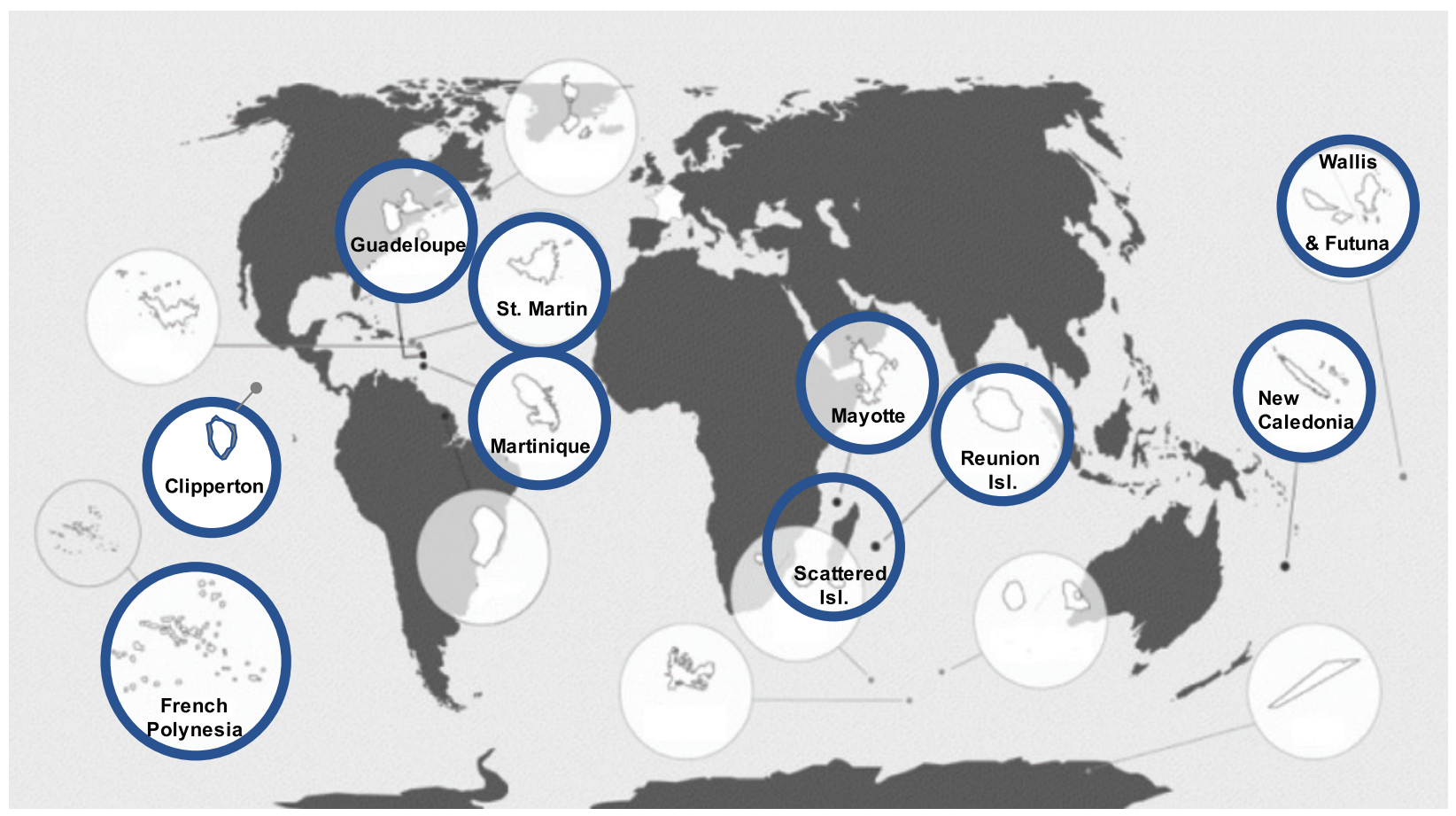

Figure 1: Distribution of French tropical overseas coral reef territories.

Named and surrounding territories are those studied in this review: four in Pacific Ocean, three in Atlantic Ocean and three in Indian Ocean. Adapted from the website pinterest.com

of the originality and importance of its reefs, which represent $15,000 \mathrm{~km}^{2}$ of the protected coral ecosystem out of the $40,000 \mathrm{~km}^{2}$ existing in French overseas territories (Payri 2018). The types of islands and reefs, i.e. continental islands with barrier reefs, high islands surrounded by fringing reefs, and atolls, are very diverse (Gardes and Salvat 2008). Coral reefs are scattered over shallow and well-illuminated tropical oceans. They are the refuge of thousands of species and the life that develops there takes many forms, hence coral reefs represent environments of great biological richness. Coral reef ecosystems cover less than $0.1 \%$ of the oceans but can contain nearly one-third of the diversity of some taxa (Bowen et al. 2013). They are therefore a crucial part of our natural heritage and the biological diversity of the planet. The productivity of coral reefs supports a very rich set of inter-dependent species. Moreover, it is the main source of food and vital resources for many islands and coastal communities. Coral reefs also act as natural breakwaters, which protect the fertile coastlines of many islands and continental countries from erosion by cyclonic swells (Ferrario et al. 2014). In addition to their intrinsic ecological value, coral reefs provide many ecosystem services that are both economically and culturally important to human populations that depend, directly or indirectly, on them (Moberg and Folke 1999). The beauty and diversity of coral reefs have always amazed the inhabitants of coastal and inland regions and constitute an important economic resource through fishing (Newton et al. 2007) and tourism (Moberg and Folke 1999) for many territories (Cinner et al. 2009).

\section{State of coral reefs in French overseas territories in relation to global change}

Gardes and Salvat (2008) provided some information relating to the state of health of coral communities in French tropical overseas territories that was divided into two categories following analysis of information gathered within the framework of permanent monitoring networks. Pacific territories (e.g. Clipperton, Polynesia, Wallis and Futuna, New Caledonia) and Mayotte, where the general state of health of coral reefs appears to have been maintained in the sites which have had long-term monitoring, owing to the reef communities' good resilience and moderate pressure from human activity (Moritz et al. 2018). Unfortunately, the French West Indies (e.g. Guadeloupe, Martinique, Saint-Barthélemy and SaintMartin) and Reunion Island, demonstrate a progressive loss in coral cover to the benefit of algal communities, particularly on the outer reef slopes, despite periods of several years of stability and even recovery. Bellwood 
et al. (2004) demonstrated the different phase-shifts taken by coral reefs following an increase of nutrients together with an increase of fishing pressure, resulting in algal biomass (macroalgae or turf) on coral reefs. Additionally, Bellard et al. (2012) argued that the multiple components of climate change were anticipated to affect all levels of biodiversity, from organism to biome levels. Under such a scenario, macroalgae on coral reefs would not be spared. Harley et al. (2012) demonstrated the separate impacts of global warming and ocean acidification (i.e. decreased $\mathrm{pH}$ ) on seaweed communities and showed that the physiological responses of seaweeds are still poorly known, with different responses to be expected, depending on region but also on algal communities. Nonetheless, the combined impacts of simultaneous warming and acidification in a more realistic climate change scenario remain poorly understood. Although global warming and ocean acidification are difficult to reverse in the near term, we can manage coral reef resilience by conserving herbivore diversity and abundance and reducing nutrient loads (Hoegh-Guldberg et al. 2007). In some parts of the Caribbean, this strategy appeared to work in practice; following high temperature and hurricane disturbances, coral recovery rates were higher in protected areas where algal cover was more effectively controlled by herbivores (Mumby and Harborne 2010). However, such control of coral resilience is no longer a priority in many countries and direct action to reduce carbon emissions has to be implemented with urgency to ensure the persistence of coral reefs into the near future (Bruno et al. 2019).

\section{Reef macroalgae, taxonomy and diversity}

Seaweeds are photosynthetic, eukaryotic organisms which include green, red and brown macroalgae. "Algae" is a generic, but not taxonomic term, as members belong to different phylogenetic lineages at the origin of their morphological, physiological and metabolic diversity (Stengel et al. 2011). Figure 2 presents this polyphyletic group with

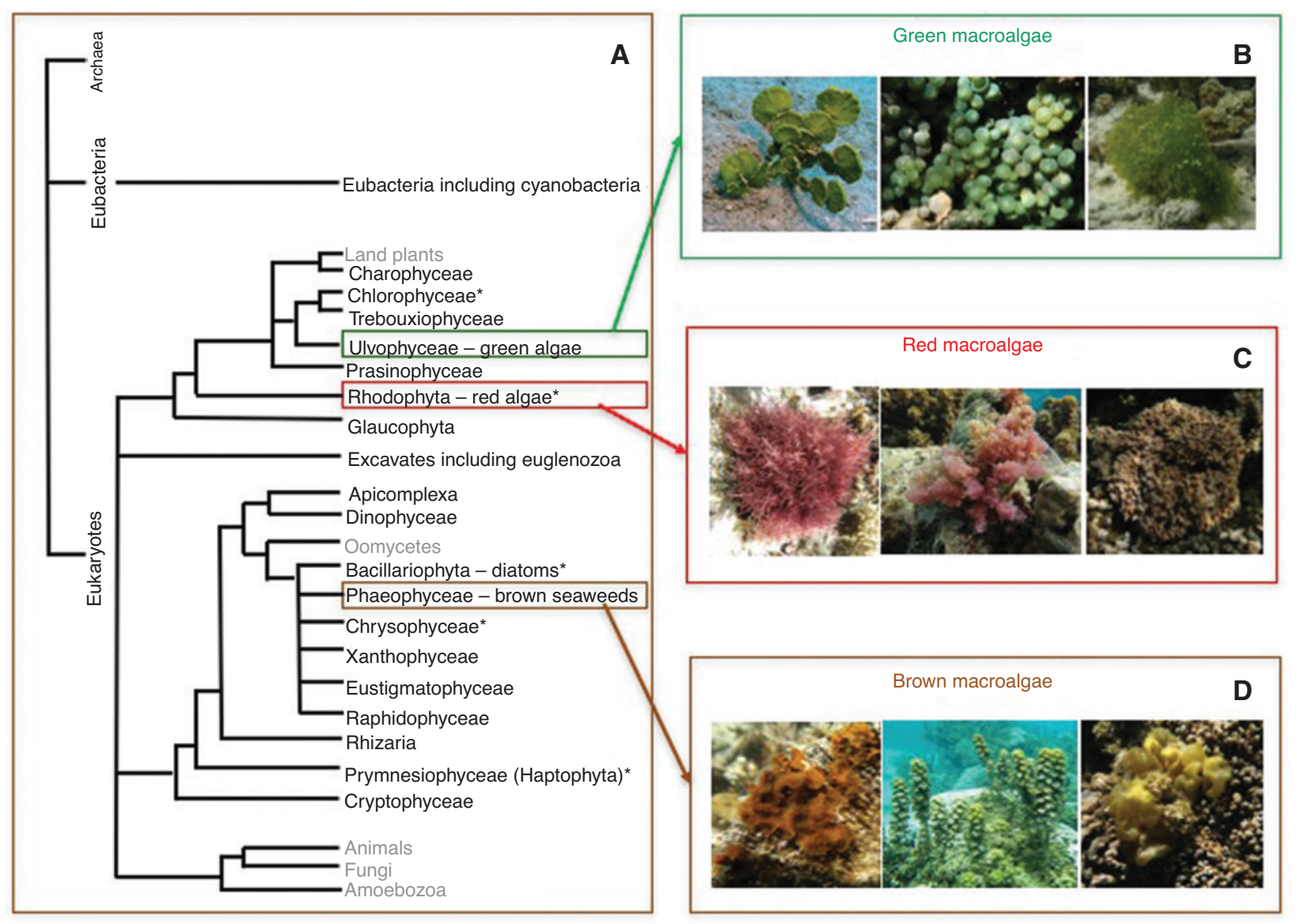

Figure 2: (A) Phylogenetic tree showing the polyphyletic group of seaweeds positioned in several lineages.

(B, C, D) Illustrations of species belonging to green, red and brown macroalgae that are commonly visible on French overseas territories: (B) Halimeda macroloba, Caulerpa chemnitzia, Boodlea composita; (C) Ganonema farinosum, Asparagopsis taxiformis, Lithophyllum kotschyanum; (D) Lobophora sp., Turbinaria ornata, Colpomenia sinuosa. Photo credits: V. Stiger-Pouvreau (T. ornata), M. Zubia (all others). 
examples of reef species, which will be dealt with in this review. Green macroalgae are distributed from cold temperate to tropical waters, but their highest diversity and natural abundance occurs in tropical and sub-tropical regions, with the abundance of several families such as the Caulerpaceae and Udoteaceae in coral reefs and associated seagrass habitats (Fong and Paul 2011). The genus Udotea J.V. Lamouroux is present only in tropical areas, the genus Halimeda J.V. Lamouroux (Figure 2B) is present in warm-temperate (i.e. the Mediterranean Sea) and tropical areas, while the complex Ulva Linnaeus/Enteromorpha Link is present anywhere in temperate and tropical areas. Different forms of green algae can be observed in coral reefs: filamentous (e.g. Chlorodesmis Harvey \& Bailey, Cladophora Kützing, Derbesia Solier), foliaceous (e.g. Ulva) and calcifying forms (e.g. Halimeda, Udotea). Red macroalgae represent the most diverse group, with the most common types found in coral reefs being the crustose coralline algae (CCA) and algal turf dominated by members of the Ceramiales (Fong and Paul 2011). Brown macroalgae, belonging to the Phaeophyceae, include fucoids, kelps, and members of the Ectocarpales and Dictyotales (Figure 2D). Phaeophyceae are dominant in temperate waters while on coral reefs, brown seaweeds are not as diversified; nevertheless, some genera, such as Sargassum C. Agardh and Turbinaria J.V. Lamouroux (Figure 2D) may dominate exposed reef areas (Fong and Paul 2011).

\section{Macroalgae and ecological functions}

Macroalgae, as key components of reef communities, provide primary production, provision of trophic resources, nutrient retention and recycling, stabilization of the reef structure through calcification, contribution to sand formation, and provision of habitats, including nursery areas for juvenile fish (Fong and Paul 2011, Koch et al.2013, Evans et al. 2014). They contribute significantly to the structure of coral reefs as primary producers, key coral reefs builders, autogenic engineers and sediment producers (Fong and Paul 2011). Non-geniculate coralline macroalgae (large forms, e.g. Hydrolithon (Foslie) Foslie) contribute to the cementation of reefs, while geniculate coralline macroalgae (articulated forms, e.g. Jania J.V. Lamouroux, Amphiroa J.V. Lamouroux) or some green calcareous macroalgae (e.g. Halimeda) contribute to the formation of sand (Montaggioni and Braithwaite 2009). The capacity of each macroalgal species to contribute to ecosystem processes, depends on several biological traits related to growth, primary productivity, fixation to the substratum and reproduction (see Loiseau et al. 2019). Consequently, reef algae are often subdivided into different functional groups to better assess their functional diversity (Littler et al. 1983, Steneck and Dethier 1994). The main functional groups are the ACG (Articulated Calcified Group; e.g. Halimeda), the CCA (Crustose Coralline Algae; e.g. Hydrolithon), turf (filamentous algae $<3 \mathrm{~cm}$ ) and fleshy macroalgae (e.g. Sargassum, Asparagopsis Montagne). Seaweeds are also at the base of food webs and provide food for invertebrates and fishes, especially in a reef environment where herbivores are numerous (Burkepile and Hay 2006). Hence, a loss of algal diversity could lead to chain disturbances throughout the food web (Hughes et al. 2007).

\section{Diversity of algae in French tropical overseas territories}

\section{Specific diversity}

Within the three oceans surrounding the French overseas territories, 2223 species of macroalgae are recognized, consisting of 1251 species of red macroalgae, 652 species of Ulvophyceae and 320 species of Phaeophyceae (Table 1). The richest diversity of macroalgae is observed in the Pacific Ocean, which comprises 1015 species, followed by the Atlantic Ocean (641 species) and the Indian Ocean (567 species). In the most diverse Pacific Ocean, red algae are the most diversified taxonomical group with 587 species, followed by 286 species of green macroalgae (Chlorophyceae) and brown seaweeds represented by only 142 species (Table 1). New Caledonia is the most diverse locality, followed by French Polynesia, Wallis and Futuna and at the extreme of this gradient of biodiversity, the isolated island of Clipperton with only 83 species (Table 1). The 641 species found in the Atlantic Ocean are grouped differently according to their geographical area. The diversity is the greatest for Martinique (332 species) and declines towards Saint Martin (187 species) and Guadeloupe (122 species). From a general point of view concerning the Caribbean Islands, the Ulvophyceae are represented by 203 species grouped into five orders, the Phaeophyceae by 97 species grouped also into five orders while the Florideophyceae is a more diversified class represented by 341 species, belonging to 14 orders. For the Rhodophyta, no Bangiales have yet been observed in French overseas' Atlantic areas. Amongst the brown algae, the orders with the most numerous species are the Dictyotales and Ectocarpales. Within green seaweeds, the orders Bryopsidales, Cladophorales and to a lesser extent the Ulvales are the 
Table 1: Number of marine algal species described for overseas communities studied in this review from published literature (references indicated below).

\begin{tabular}{lrrrrr}
\hline Ocean & $\begin{array}{r}\text { Green } \\
\text { macroalgae }\end{array}$ & $\begin{array}{r}\text { Brown } \\
\text { macroalgae }\end{array}$ & $\begin{array}{r}\text { Red } \\
\text { macroalgae }\end{array}$ & $\begin{array}{r}\text { Total per } \\
\text { region }\end{array}$ & $\begin{array}{r}\text { Total per } \\
\text { Ocean }\end{array}$ \\
\hline Atlantic Ocean & 203 & 97 & 341 & & \\
Guadeloupe & 37 & 15 & 70 & 122 & \\
Martinique & 100 & 51 & 181 & 332 & 641 \\
Saint Martin & 66 & 31 & 90 & 187 & \\
Indian Ocean & 163 & 81 & 323 & & \\
Scattered Islands & 51 & 24 & 66 & 141 & \\
Reunion Island & 65 & 33 & 127 & 225 & 567 \\
Mayotte & 47 & 24 & 130 & 201 & \\
Pacific Ocean & 286 & 142 & 587 & & \\
Clipperton & 23 & 11 & 49 & 83 & \\
French Polynesia & 82 & 32 & 195 & 309 & \\
New Caledonia & 140 & 88 & 215 & 443 & 1015 \\
Wallis et Futuna & 41 & 11 & 128 & 180 & \\
Total & 652 & 320 & 1251 & & 2223 \\
\hline
\end{tabular}

Atlantic Ocean: Gargominy et al. 2017, Rodriguez-Prieto et al. 1999. Indian Ocean: Mayotte: Gargominy et al. 2017. Reunion Island: Payri 1985, Ballesteros 1994, Zubia et al. 2018. Scattered Islands: Mattio et al. 2016. Pacific Ocean: French Polynesia: N'Yeurt and Payri 2006, 2007, 2010. Wallis and Futuna: N’Yeurt and Payri 2004. Clipperton: Payri et al. 2009. New Caledonia: Payri 2007.

most diverse. In the red macroalgae, the most numerous orders are the Ceramiales, followed by the Nemaliales, and to a lesser extent the Gigartinales and Rhodymeniales. The 567 species reported from the Indian Ocean are grouped differently depending on the geographical area (Table 1 and references therein). The highest diversity is found in Reunion Island (225 species), following by Mayotte (201 species) and by Scattered Islands (141 species) (Table 1). Only one inventory was performed for Mayotte (Coquegniot et al. unpubl. data) and another single one for the Scattered Islands (i.e. Gloriosos, Juan De Nova and Europa; Mattio et al. 2016), whereas many studies on algal composition have been made recently in Reunion Island (Ballesteros 1994, Zubia et al. 2018). The diversity of macroalgae varies in accordance with the habitat diversity and the surface of each territory, but also depends on the sampling effort and that had varied with the territory.

From a general point of view, among the coral reefs covered by this review, differences noted in the diversity of macroalgae between the three oceans could be explained by the fact that the macroalgae belong to two different biogeographic regions. Indeed, the global patterns in reef development can be explained by looking at the tectonic and climatic history of reefs. With the closure of the Tethys Sea, the waters of the Indian Ocean and Western Pacific Ocean were separated from those of the Atlantic Ocean and far Eastern Pacific. Macroalgal communities in each began to develop distinctive characteristics (Johnson et al. 1996, Spalding 2001; for more details on the geological events, see Coastes and Obando 1996). One would expect a low diversity of macroalgae in the Atlantic Ocean due to massive extinctions, which occurred during the Pliocene/Pleistocene glaciations (Coastes and Obando 1996). Conversely, higher diversity exists in the Indo-Pacific region, as the period of extinction was not so extreme (Spalding 2001). Bellwood et al. (2004) also noted a difference in species richness and taxonomic composition among functional groups, markedly different between the Great Barrier Reef and Caribbean region. These authors underlined that this difference was largely due to a biogeographic legacy of the evolutionary history of isolation and loss of taxa in the Caribbean Basin. However, these assumptions should be considered with caution since the sampling effort between these different territories is not comparable. Some territories were extensively sampled (e.g. French Polynesia, New Caledonia) whilst others were sampled only once (e.g. Scattered Islands). Moreover, some inventories are not comparable because some studies use molecular tools while others only use traditional morphological identification. Traditional morphological species definitions show insufficient resolution in seaweeds presenting morphological plasticity due to their environment, but also due to evolutionary events such as convergence and cryptic speciation (Saunders and Lehmkuhl 2005, Verbruggen 2014). The development of high-performance molecular tools now makes it possible to improve species identification or delimitation in different ways. Molecular analyses 
have shown the existence of cryptic species, i.e. species that cannot be morphologically resolved but are genetically different (Bickford et al. 2007). The recent adoption of molecular approaches has thus revealed unsuspected genetic diversity within several groups of marine macroalgae (De Clerck et al. 2013). A notable example is the brown genus Lobophora J. Agardh (Dictyotales, Phaeophyceae) that until 2014 included only 6 taxonomically accepted species. Recent molecular studies have revealed the presence of more than 100 evolutionary taxonomic units of Lobophora around the world, from tropical to warm temperate regions (Vieira et al. 2014). Conversely, the highly morphologically plastic genus Sargassum, with 484 morphologically recognized species (Mattio and Payri 2011) was resolved in French Polynesia from 18 taxa to only 3 valid species using molecular tools (Mattio et al. 2008). In the Western Atlantic, the genus Sargassum is composed of 38 taxa and main species inhabit the shallow rocky bottoms (benthic species) of the Caribbean coastlines; however, only two species are known to be holo-pelagic, i.e. entirely pelagic throughout the entire life cycle, i.e. S. fluitans (Børgesen) Børgesen and S. natans (Linnaeus) Gaillon, with different morphological types described in both species (Schell et al. 2015), that are known to form the Sargasso Sea, and which can become stranded on the coasts (see later in this manuscript on Sargassum beachings). The delineation between different Sargassum varieties and morphotypes still remains unclear (Mattio and Payri 2011). For instance, the concatenated sequences of nuclear and cytoplasmic markers did not separate S. natans and S. fluitans from other related species inside the Sargassum section (Mattio and Payri 2011, AmaralZettler et al. 2017, Sissini et al. 2017). An oceanographic expedition was organized by the Mediterranean Institute of Oceanography from Marseille (Thibaut 2017), in which the first author participated, and during which numerous Sargassum samples were collected from Guyana to Sargasso Sea, and highlighting the identification of three holo-pelagic morphotypes. Analyses are underway on the specific identification of holo-pelagic Sargassum (Thibaut, pers. com.). One should also point out the existence of cryptic diversity at different levels of the taxonomy in some macroalgae. As an example, in the red genus Asparagopsis, using molecular tools, Dijoux et al. (2014) highlighted two cryptic species and then a new clade within the species A. armata Harvey as well as a new clade within A. taxiformis (Delile) Trevisan. These authors demonstrated the need for geographically extensive sampling efforts when studying taxa that have been introduced globally and that are likely to hide species complexes. Similarly, Kooistra et al. (2002) studied different species of Halimeda sampled worldwide and described the historical ecology and phylogeography of this genus using morphological and molecular tools. These authors showed that, following the closure of the Panamanian Isthmus, allopatric speciation through vicariance gave rise to two sister taxa, i.e. Atlantic and Indo-Pacific sister groups; each daughterpair giving rise to additional convergent species in similar habitats of these different oceans (Kooistra et al. 2002). Recently, new chemo-taxonomic tools for the differentiation of macroalgal species have emerged (Fiehn 2002, Jégou et al. 2010, Govindaraghavan et al. 2012, Kumar et al. 2016), especially metabolomic approaches using analytical techniques such as high-resolution magic angle spinning nuclear magnetic resonance (HR-MAS NMR) or liquid chromatography-mass spectrometry (LC-MS) analysis and allowing species identification. For example, the widespread tropical brown genus Turbinaria was used for developing chemo-taxonomical procedures (Le Lann et al. 2008). In the Atlantic Ocean, T. turbinata (Linnaeus) Kuntze is present (Rohfritsch et al. 2007), while in the Indian and Pacific Oceans, three other species can be observed: T. ornata (Turner) J. Agardh in French Polynesia, T. conoides (J. Agardh) Kützing and T. ornata in New Caledonia, and three different species, $T$. conoides, $T$. ornata and T. decurrens Bory in the Indian Ocean with a genetic diversity extremely low in French Polynesia (Rohfritsch et al. 2010). Despite the limited number of species, i.e. almost 22 recognized species (Guiry and Guiry 2019), this genus is morphologically complex as authors recognize a wide variety of forms (see Wynne 2002 for a review of the genus). Moreover, the use of morphological characters only has led to many taxonomic errors (Rohfritsch et al. 2007). For this genus, Le Lann et al. (2008) used HR-MAS NMR spectra combined to molecular analysis (as a reference) with the aim to find chemical differences at the species level, leading, without error, to the specific identification of Turbinaria samples. Le Lann et al. (2014) isolated a lipidic chemical marker, turbinaric acid, specific to T. conoides. A metabolomic approach was also carried out in the red alga Asparagopsis taxiformis from French overseas territories (SEAPROLIF program) in order to assess links between bioactivities and metabotypes with macroalgal invasiveness (Greff et al. 2017).

\section{From algal diversity to valorization}

As described in Stengel et al. (2011), the diversity of macroalgae, belonging to several different lineages, living in diverse environments (i.e. rocky shores, salt marshes, intertidal and subtidal areas, sheltered versus exposed 
areas) has forced these organisms to optimize their competitive survival in a range of ecological niches and has then led to the co-evolution of a diverse array of biochemical constituents. The diversity of macroalgae, and the molecules they produce, has therefore led to their exploitation in many industrial sectors worldwide, particularly in Asia and Europe, strongly for the food market ( $76 \%$ of the world market) (Chopin 2012).

\section{Diversity of metabolites produced by French overseas reef macroalgae}

As mentioned in Lucena et al. (2018), the ocean shelters most of the global biodiversity that makes the marine environment a great reservoir of bioactive natural products that are mostly not found in the terrestrial environment. Seaweeds are a great source of bioactive natural products, as demonstrated by many reviews on this subject (e.g. Holdt and Kraan 2011, Wijesinghe et al. 2011, Pereira et al. 2012, Pal et al. 2014, Blunt et al. 2015, Hamed et al. 2015). There is no doubt that French tropical overseas territories present a potential of valorization of their main macroalgal orders known to produce active compounds (Kornprobst 2014, Blunt et al. 2015). Among the many groups of biologically active molecules found in macroalgae, some examples are shown in Figure 3 and discussed below.

\section{Carbohydrates}

Depending on the class of macroalgae, different polysaccharides can be isolated from them. Stiger-Pouvreau et al. (2016) reviewed carbohydrates produced by seaweeds. Among them, starting with cell-wall polysaccharides, there are carrageenans and agar extracted from red seaweeds, alginates and sulfated polysaccharide from brown seaweeds and ulvan from green seaweeds (see Figure 3 for some structures of polysaccharides). Small carbohydrates with osmo-regulatory properties, i.e. osmolytes, can be extracted from seaweeds, including floridoside from red seaweeds, dimethylsulfoniopropionate (DMSP) in green seaweeds and mannitol in brown seaweeds (Figure 3). These carbohydrates are not all studied in macroalgae encountered in the French overseas territories. Experimental cultivation of Caribbean seaweeds as potential sources of carrageenan for the extractive industry began in the 1970s. Using seed material from St. Martin, Barbaroux et al. (1964) attempted to cultivate Eucheuma J. Agardh species, i.e. E. isiforme (C. Agardh) J. Agardh and E. spinosum J. Agardh, in Guadeloupe and Martinique. They concluded that the economic returns would have been too low for production in the Atlantic Ocean as compared to Asian sources of carrageenophytes. In the Pacific Ocean, alginate yields in two Sargassaceae species, i.e. Sargassum pacificum Bory and Turbinaria ornata were in the range of 6.0-21.1\% DW, with the highest values shown in T. ornata

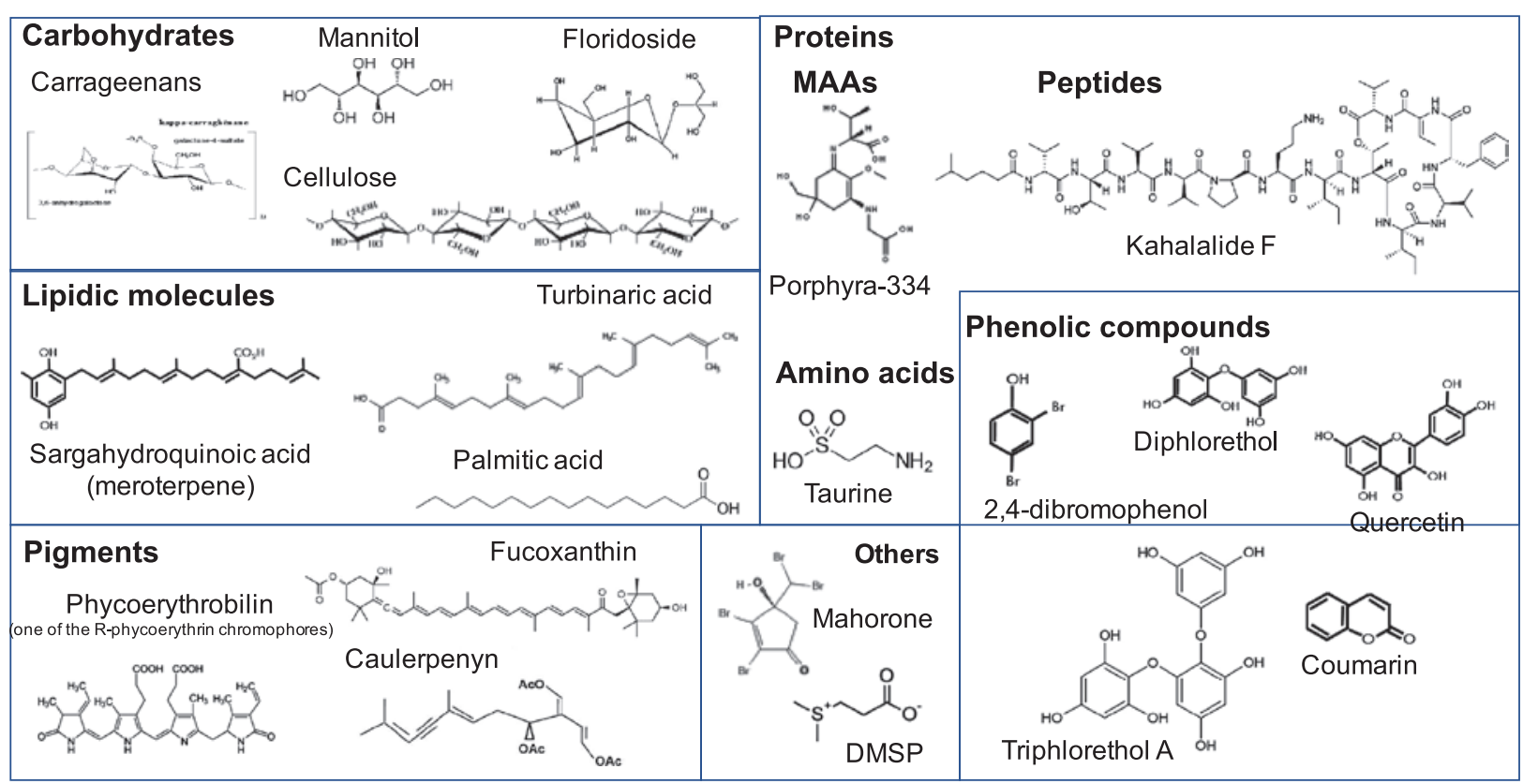

Figure 3: Structures of different types of molecules/natural compounds isolated from tropical macroalgae. MAAs: Mycosporine-like amino acids; DMSP: dimethylsulfoniopropionate. 
(Zubia et al. 2008). These ratios are lower than those from other alginophytes normally used in the industry (e.g. 1338\% DW; Perez 1992). Zubia et al. (2008) demonstrated that the viscosities of Polynesian seaweed alginates were low (e.g. 9-78 $\mathrm{mPa} \cdot \mathrm{s}$ ), which was in agreement with the frequent observations of low viscosity in alginates obtained from tropical or sub-tropical species, as compared to cold-water species (McHugh 1987). The M:G ratios, i.e. the ratio between mannuronic and guluronic acids, were quite high (e.g. 1.25-1.42) and favored the use of Polynesian seaweed alginates for the manufacture of strong gels, as reported previously for species of the genera Sargassum and Turbinaria (Minghou et al. 1984, McHugh 1987, Larsen et al. 2003, Davis et al. 2004, Jothisaraswathi et al. 2006). Sulfated polysaccharides, rich in fucose, including fucoidans, were also extracted from French Polynesian $T$. ornata and presented anti-tumoral activities (Deslandes et al. 2000). Mannitol (Figure 3), a sugar alcohol found in brown seaweeds, was studied in Polynesian seaweeds and its content ranged from 3.90 to $14.42 \%$ DW, with S. pacificum displaying a higher mannitol content than T. ornata and other Sargassaceae (Zubia et al. 2008).

\section{Proteins}

The protein content of seaweeds has received little attention to date. In their meta-analysis of protein founds in seaweeds, Angell et al. (2016a) determined the protein and amino-acid contents of seaweeds, according to their classes and origin (i.e. temperate, tropical or polar). The protein content varied significantly with the species and the period of the year, with green and red seaweeds having a protein content almost 33-45\%, higher than that of brown seaweeds (e.g. 27-31\%, Angell et al. 2016a). These authors showed also that the highest amino acid content was 32.2\% DW for green seaweeds, $28.7 \%$ DW for red seaweeds and $15.9 \%$ DW for brown seaweeds, with tropical species in an intermediate position, compared to temperate and polar examples. Moreover, certain amino acids present potential biological activity, i.e. mycosporinelike amino acids (MAAs) and taurine (Figure 3, with the example of Porphyra-334) that have been studied to some extent. MAAs are molecules of low molecular weight ( $<400 \mathrm{Da})$, water-soluble, with a high molar extinction coefficient (between 28,000 and 50,000 $\mathrm{M}^{-1} \cdot \mathrm{cm}^{-1}$ ), with an absorption maximum ( $\lambda \max$ ) between 310 and $362 \mathrm{~nm}$ (reviewed in Lalegerie et al. 2019). Taurine recently became popular as an ingredient in dietary supplements, functional foods, and beverages, and it has been used in infant milk formulas since the 1980s to mimic human milk (Surget et al. 2017). The genera Gelidium J.V. Lamouroux, Gracilaria Greville and Grateloupia C. Agardh, which occur in tropical areas, present high levels of taurine and also contain interesting MAAs that could be targeted in French overseas territories. Phycobiliproteins, another group of bioactive proteins found in marine red algae, are water soluble, colored, and highly fluorescent compounds consisting of a protein backbone to which prosthetic bilin chromophores (tetrapyrolic open chain) are covalently bound. Major phycobiliproteins including phycoerythrin, phycocyanin, allophycocyanin, and phycoerythrocyanin, most of which are not well studied and would benefit from being evaluated in French overseas territories. Moreover, some interesting bioactive peptides such as kahalalides (e.g. Kahalalide F, Figure 3) have been found in tropical species (Hammann et al. 1996). Kahalalides were isolated from the tropical green seaweed genus Bryopsis J.V. Lamouroux (Hamann et al. 1996), and the University of Hawaii later licensed this compound to the industrial Spanish Company PharmaMar.

\section{Lipids}

The term lipid includes a wide range of molecules, such as fatty acids and their derivatives, carotenoids, terpenes, steroids, but also some lipidic compounds grafted on phenolic compounds such as meroditerpenes (Jégou et al. 2010, 2012) or on carbohydrates, such as glycolipids encountered in the genus Sargassum (Plouguerné et al. 2010). Generally, the lipid content of seaweeds is very low, from 0.9 to $4 \%$ DW, i.e. representing a low-fat food. On the other hand, because of seasonal variability in Total Lipids (TL), some Dictyotales brown seaweeds could reach a TL of $10-12 \%$ dw and, could contain over $40 \%$ of the TL in $\omega-3$ PUFAs (polyunsaturated fatty acids) (Gosch et al. 2012). It was reported that tropical seaweeds have significantly lower lipid contents than cold-water ones (Sánchez-Machado et al. 2004). In spite of their low contents, seaweed-derived lipids contain many types of bioactive lipidic compounds, such as $\omega-3$ PUFAs, $\omega-6$ arachidonic acid, fucoxanthin (Figure 3), fucosterol, terpenes, glycolipids and some polyphenols (Fleurence et al. 2012, Wells et al. 2017). Some species of macroalgae could therefore be used as feedstock for dietary supplementation (Angell et al. 2016b). Zubia et al. (2003) reported the fatty acid composition of the two brown macroalgae, S. pacificum and T. ornata from French Polynesia. Both species showed a similar fatty acid composition with palmitic acid (16:0), oleic acid (18:1n9) and arachidonic acid as the main components (Zubia et al. 2003). Fatty acids could represent chemo-taxonomic markers, as demonstrated 
previously with turbinaric acid produced in T. conoides (Le Lann et al. 2014). Terpenes will be discussed in the section devoted to secondary metabolites.

\section{Pigments}

Macroalgae are autotrophic organisms, which use diverse types of photosynthetic pigments for harvesting light. The variability of the fucoxanthin content was studied in some South Pacific Sargassaceae species (Le Lann et al. 2012). These authors demonstrated that the fucoxanthin content varied between (a) genera, i.e. Sargassum versus Turbinaria; (b) the archipelago from which the material was collected, i.e. New Caledonia, Solomon and Fiji Islands; (c) geomorphological features, i.e. fringing, inner and outer barrier reefs and the depth of each collection site. Sargassum species produced more fucoxanthin than those of Turbinaria and species near the surface had more fucoxanthin than deeper species (LeLann et al.2012). Theseauthors demonstrated that Sargassum aquifolium (Turner) C. Agardh, from deep and intermediate areas in the water column of the fringing reef, produced respectively $103.5 \pm 3.8$ and $148.2 \pm 2.4 \mathrm{mg} \mathrm{g}^{-1} \mathrm{DW}$ of fucoxanthin. Turbinaria conoides and T. ornata from New Caledonia produced less fucoxanthin $\left(58.361 \pm 4.235\right.$ and $\left.15.016 \pm 1.392 \mathrm{mg} \mathrm{g}^{-1} \mathrm{DW}\right)$ for individuals living in intermediate water depths of the fringing reef (Le Lann et al. 2012). Moreover, they hypothesized that in tropical Sargassaceae, fucoxanthin could play a key role in the photo-protection of the thallus, as demonstrated for other Sargassum species by Heo and Jeon (2009). Fucoxanthin is known to be an antioxidant molecule; Le Lann et al. (2012) demonstrated that all fucoxanthin extracts from those Sargassaceae tested presented a radical scavenging activity using the 2,2-diphenyl-1-picrylhydrazyl (DPPH) radical scavenging assay, as already shown in fucoxanthin extracted from edible Sargassum species (Yan et al. 1999, Heo and Jeon 2009).

\section{Secondary metabolites}

In tropical regions, and particularly in coral reefs, ecological pressures on marine organisms are very high due to the high biodiversity of these ecosystems. Defense against predators, competition for space, maintenance of an epiphyte-free surface, defense against pathogenic microorganisms and successful reproduction require the production of many secondary metabolites (Hay 1997). Algae have thus acquired diversified chemical defenses over a long evolutionary history. Algae have had to develop multiple defensive strategies against herbivores, sometimes making some of them very unpalatable through molecules or carbonates they have concentrated. However, herbivores have responded by developing counter-offensive strategies (Hay 1997). This "chemical arms race" has led to a great diversification of secondary metabolites in algae, particularly in coral reefs where herbivore pressure is very high (Demko et al. 2017). Additionally, there is significant competition for space between algae and corals, resulting in the production of many secondary metabolites (Rasher and Hay 2010, 2014).

From a general point of view, there are two main families of secondary metabolites in algae: terpenes and phenolic compounds, which differ depending on the species; brown seaweeds are known to produce both as secondary metabolites. For example, the genus Lobophora from the Dictyotaceae has many biological activities such as anti-microbial, anti-viral, anti-coagulant and anti-inflammatory activities (Vieira et al. 2017). Dictyotacean species have proven to be a particularly rich and diverse source of natural products (Maschek and Baker 2008, Blunt et al. 2015). The family Sargassaceae and, in particular, the genera Sargassum and Turbinaria, also show original and active molecules. Their ubiquity in many regions (for instance the Caribbean and volcanic islands in French Polynesia), would facilitate their exploitation (Zubia et al. 2003), although the high arsenic content of Caribbean Sargassum species does not allow their use in certain industrial sectors, such as direct applications to crops or for animal and human consumption (Milledge and Harvey 2016). In red seaweeds, the most characteristic aspect of the chemistry of secondary metabolites is the extreme abundance of halogenated derivatives, particularly bromophenols that have a wide range of biological activities (antioxidant, anti-microbial, anti-tumor, anti-viral and anti-inflammatory) (Kornprobst 2014). As an example, Asparagopsis spp. are particularly interesting due the production of a high diversity of low molecular weight, halogenated compounds, which exhibit an array of biological activities (Greff et al. 2014). Phytochemical investigations performed on A. taxiformis gametophyte stages from Mayotte revealed two new highly brominated cyclopentenones named mahorone and 5-bromomahorone (Figure 3; Greff et al. 2014). They are the first examples of natural 2,3-dibromocyclopentenone derivatives. A standardized eco-toxicological assay on the bioluminescent marine bacterium Vibrio fischeri Beijerinck was used as an assessment of their role in the environment, revealing high toxicities (reduction of the initial bioluminescence of bacteria) for both compounds (Greff et al. 2014). Additionally, both compounds exhibited mild anti-bacterial activities against the human pathogen Acinetobacter baumannii Bouvet \& 
Grimon. Samples from Martinique and French Polynesia showed the lowest bioactivities, whereas samples from Mayotte showed the highest values. Asparagopsis taxiformis from other tropical sites (New Caledonia, Reunion Island and Guadeloupe) exhibited intermediate bioactivities. The production of chemical defenses by A. taxiformis does not match the macroalgal genetic lineage and seems more driven by the environment (Greff et al. 2017). Most of the secondary metabolites of green seaweeds comprise terpenes and derivatives of aromatic compounds (Kornprobst 2014). The Order Bryopsidales, which includes the genera Avrainvillea Decaisne, Bryopsis, Caulerpa J.V. Lamouroux, Codium Stakhouse, Halimeda and Udotea, is very interesting for its richness in secondary metabolites, especially in tropical species. A total of four bromophenols were isolated from Avrainvillea, including brominated diphenylmethanes, monoaryl phenol, and tetra-arylphenol (Jesus et al. 2019). An avrainvilleol was isolated from A. longicaulis (Kützing) G. Murray \& Boodle and A. nigricans Decaisne and showed inhibitory activities against many bacteria and the human KB cancer cell line (Colon et al. 1987). Species of Caulerpa were among the first green algae that were investigated by natural product chemists (Paul et al. 1987). The chemo-diversity of this genus is particularly high with 125 compounds isolated so far (MarinLit 2019). Many bioactive compounds, essentially sesquiterpenoid and diterpenoid metabolites, are of cosmetic, cosmeceutical, nutraceutical, and pharmaceutical importance (Kornsprobst 2014, De Gaillande et al. 2017, Máximo et al. 2018). However, caution should be taken with the use of Caulerpa extracts for biotechnological purposes since this genus is also very well known for its high toxicity (Pesando et al. 1996). Caulerpenyne represents the most abundant cytotoxic sesquiterpenoid in Caulerpa. It inhibits the growth of microorganisms, interferes with the development of fertilized sea urchin eggs, and some of its degradation products reduce the palatability of the alga thereby lowering grazing pressure by some fishes and invertebrates (Tejada et al. 2016). However, the toxicological risks to humans are considered minimal according to the study of Parent-Massin (1996). In New Caledonia, Caulerpa species were investigated for caulerpicin activity in the 1980s for cosmetic purposes, but the highly publicized invasion of Caulerpa taxifolia (M. Vahl) C. Agardh in the Mediterranean Sea brought the project to an immediate halt (Vidal et al. 1984).

Chemically, all terpenes are built from a similar ramified hydrocarbon chain: isoprene, which gives the molecule an apolar characteristic. Terpenes can have a linear, monocyclic, bicyclic or rearranged (cyclization by a heteroatom) structure. In brown algae, terpenes are known in two main orders: the Fucales and the Dictyotales.
Fucales possess only linear diterpenes and Dictyotales only cyclic diterpenes and sesquiterpenes (Kornprobst 2014). Meroterpenes (Figure 3) are composed of a complex of terpenic and aromatic parts that gives interesting properties to these compounds. The brown genus Lobophora (Dictyotales) represents an important algal component in coral reef ecosystems (Vieira et al. 2017) and is particularly rich in natural products and predominantly diterpenes. The terpenoids isolated from the Dictyotaceae exhibit various types of bioactivity, such as feeding deterrence, anti-fungal, cytotoxic, antibiotic, anti-inflammatory, insecticidal or anti-viral activities (Vieira et al. 2017). However, in the study by Gaubert et al. (2019), no terpene derivatives were identified in the metabolome of the four species of Lobophora studied from New Caledonia. This observation could lead to interesting chemo-taxonomic considerations for this group and the search for terpene synthases in a larger set of Dictyotales. In the Atlantic Ocean, Paul et al. (1987) isolated terpenes from the red macroalga Ochtodes secundiramea (Montagne) M. Howe, collected at Pointe Dunkerque (Martinique, French Antilles) which presented deterrent activities against herbivores (amphipods, parrot fishes). In the same area, lipidic compounds from the brown alga Sargassum polyceratium Montagne showed antifouling activities against terrestrial and marine bacteria and interfered with embryonic development in three marine tropical invertebrates, namely a sea urchin, a bivalve and a worm (Thabard et al. 2011).

Phenolic compounds represent molecules made up of one or more hydroxyl groups $(-\mathrm{OH})$ directly bonded to an aromatic hydrocarbon group, and include a large range of compounds, from simple molecules such as phenolic acids and polyphenolic compounds, that are produced by all classes of macroalgae, to more complex polyphenols such as phlorotannins (Figure 3), encountered in brown seaweeds (reviewed by Gager et al. 2019). Phenolic compounds can be halogenated or sulfated, conferring different and often stronger biological activities than those without these functional groups (Gager et al. 2019). As phenolic compounds contain at least one aromatic ring, they show intense absorption near $270 \mathrm{~nm}$ in the UV-B region of the spectrum. In the green algae, non-typical phenolic compounds have been characterized, such as bromophenols, coumarins and trihydroxycoumarin, occurring in green seaweeds such as Caulerpa species or Dasycladus vermicularis (Scopoli) Krasser (Pérez-Rodriguez et al. 2003, reviewed in Gager et al. 2019). In the latter species, Kurth et al. (2015) described a sulfated hydroxylated coumarin derivative as a storage metabolite involved in activated defense against fouling organisms. Another example of phenolic compounds in green seaweeds, is 
salicylic acid, also known as 2-hydroxybenzoic acid, produced by the green calcified Halimeda incrassata (J. Ellis) J.V. Lamouroux (Novoa et al. 2011). Simple brominated polyphenolic compounds, together with flavonoids and catechins, were isolated from Halimeda opuntia (Linnaeus) J.V. Lamouroux which was proven to be a source of natural antioxidants, such as cinnamic, gallic and caffeic acids (Mancini-Filho et al. 2009). In brown seaweeds, phenolic compounds or phlorotannins are polymers of phloroglucinol and are classified into five groups, i.e. fucols, phlorethols, fucophloroethols, fuhalols and eckols (Figure 3), according to their chemical structure (reviewed in Stiger-Pouvreau et al. 2014, Gager et al. 2019). Several studies on phenolic content were carried out in French tropical overseas territories in order to examine the variability of phenolic content of Fucales in relation to the type of biomass, i.e. fixed/floating thalli (Zubia et al. 2003), the sites and the season of harvest (Stiger et al. 2004, Zubia et al. 2008, Le Lann et al. 2012), the ontogeny (Stiger et al. 2004), the position of algae in the water column and also to variability among genera and species (Zubia et al. 2007, 2008, Le Lann et al. 2012). Moreover, the pool of phenolic compounds from the South Pacific genera Turbinaria and Sargassum is mainly composed of compounds of low molecular weight <2000 Da (Le Lann et al. 2012).

\section{Applied uses of French tropical overseas macroalgae}

The diversity of molecules produced by seaweeds around the world, has led people to value them in different fields. The following sections present, by industrial sector, the use of tropical macroalgae from the French overseas territories.

\section{Algae as vegetables for human consumption}

The use of algae for human food is an important market, due to the extent of traditional algal consumption in Asian countries, particularly in China, Korea and Japan (FAO 2018). Over the past decade, we have seen a boom in the use of edible algae in Western countries (Le Bras et al. 2015). Algae are a "healthy food" because of their many nutritional properties: low lipid content, high content of polysaccharides which act as dietary fiber, rich in minerals like calcium and magnesium, and the presence of polyunsaturated fatty acids, phenolic compounds, vitamins and various other biological actives (for example, antioxidants; see the previous section on the chemo-diversity of macroalgae) (MacArtain et al. 2007, Mohammed et al. 2012, Wells et al. 2017). The global trade in tropical algal species for food is much less developed in tropical countries than in temperate ones despite their nutritional quality and extensive local consumption (Matanjun et al. 2009, Kumari et al. 2010, Dixit et al. 2018). For instance, Zubia and Mattio (2019) described 38 species of tropical algae which are consumed in the Indo-Pacific Islands, including French Polynesia which has, in some islands, a great tradition of consuming edible seaweeds. Polynesians consumed eleven species of seaweeds (Conte and Payri 2002, 2006, De Gaillande et al. 2017), 6 of them of the genus Caulerpa. Ancient inhabitants of the Marquesas archipelago, especially Ua Uka Island, consumed five green seaweeds (Caulerpa racemosa var. turbinata (J. Agardh) Eubank, Cladophora patentiramea (Montagne) Kützing, Codium arabicum Kützing, Ulva flexuosa Wulfen, Ulva lactuca Linnaeus and the brown alga Chnoospora minima (Hering) Papenfuss (Conte and Payri 2002). Harvesting of seaweeds used to be preferentially reserved for women (Chamberlain and Pickering 1998, Conte and Payri 2006). In most of the Islands this tradition has been lost except in the Australs Archipelago where Caulerpa is very often consumed (De Gaillande et al. 2017). The main species collected in these Islands (Tubuai, Raivavae, Rimatara, Rurutu and Rapa) is Caulerpa chemnitzia (Esper) J.V. Lamouroux (=C. racemosa var. turbinata) known as sea grapes ("rému" or "imu topua" in Polynesian language) but some other nongrape species of Caulerpa could be collected occasionally (C. bikinensis W.R. Taylor, C. cupressoides Vahl C. Agardh var. lycopodium, C. sertularioides (S.G. Gmelin) M. Howe). Caulerpa are collected on the shore of the lagoon, taking care not to crush or tear the harvested pinnules. Then, the harvested fronds are rinsed with seawater in colanders, and deposited in wicker baskets, or packed in banana or papaya leaves. Algae are not a dish, as such, but are served like a salad and usually eaten with lemon juice and coconut milk. Traditionally, the collection of seaweed was a family affair and therefore harvested at subsistence level and consumed locally. However, in recent years, the popularity of "rému" has increased and now this alga, collected in Tubuai, is sold frequently in Polynesian markets. In 2014, a pilot farm for the cultivation of $C$. racemosa (Forsskål) J. Agardh var. turbinata was built to increase the production but without success (research program "CAVIAR VERT", de Gaillande et al. 2017, https://wwz.ifremer.fr/umr_eio/Vie-scientifique/ Programmes/CAVIAR-VERT). As part of this project, a landbased mariculture of Caulerpa in artificial tanks is now considered in order to prevent crop loss and to achieve better control of the quality of seaweeds and also more regular and better yields. The culture of other edible species will be 
tested including the two red algae Acanthophora spicifera (M. Vahl) Børgesen and Gracilaria parvispora I.A. Abbott. Acanthophora spicifera is used in several tropical Pacific countries and is consumed as salads, as a spice, and as a thickening ingredient in cooking (South 1993, Trono 1999, Payri et al. 2000, Duarte et al. 2004, Dhargalkar and Pereira 2005). Gracilaria parvispora, known also as "long ogo", was formerly the most important edible seaweed in Hawaii (Glenn et al. 1998). Caution needs to be taken with seaweed farming projects as A. spicifera and G. parvispora have become invasive in some regions (O'Doherty and Sherwood 2007, Nelson et al. 2009, Garcia-Rodriguez et al. 2013). The quantity of seaweeds consumed as food in Atlantic overseas territories, and the Caribbean in general, is small compared to the amounts used in Pacific islands. In Caribbean Islands, most of the population collects red macroalgae, such as Eucheuma spp., Gracilaria spp., consuming them as food or using them to prepare locally-important drinks and desserts with aphrodisiac properties (Espinoza-Avalos 1994). Furthermore, Díaz-Piferrer (1969) noted six genera of Chlorophyta, in which 20 species were useful for nutritional flours.

\section{Algae as a source of phycocolloids}

The market of hydrocolloids from algae constitutes a large percentage of the world production of colloids (Buschmann et al. 2017, Bixler and Porse 2011). Carrageenans are mainly extracted from two genera of tropical red seaweeds: Eucheuma and Kappaphycus Doty (Setyawidati et al. 2017, 2018a). However, in French overseas territories, this production has not been fully developed. Some trials were done in the 1980s to exploit natural populations of Eucheuma occurring in the Lesser Antilles (Guadeloupe, Saint Martin) but these efforts were abandoned quickly (Barbaroux et al. 1964). Indeed, these authors explained this abandonment citing the high labor costs and the high cost of seeding by cuttings. As long as the cultivation of Eucheuma spinosum is done by cuttings, it cannot be a main activity in the French West Indies; at most it would be a secondary activity because it is not profitable enough. Kappaphycus farming has been strongly promoted in the Pacific region, i.e. South Pacific countries such as Fiji, Kiribati, the Solomon Islands and French territories, because it requires a low level of technology and investment, can be operated at the family level, has relatively little environmental impact, does not require refrigeration or high-tech, post-harvest processing within the country, and is normally compatible with traditional fishing and other subsistence uses of the inshore environment. However, these crops are not profitable in French Polynesia and New Caledonia due to the high cost of living. More than ten different species of Gracilaria are used for agar extraction (Zubia and Mattio 2019). In French Polynesia, a new project driven by the second author on seaweed farming of Gracilaria is being implemented to develop a market for that genus, drawing on existing multi-trophic aquaculture studies on this genus: Gracilaria/Eucheuma and abalone in the Philippines (Largo et al. 2016), Gracilaria/Caulerpa and molluscs in Thailand (Chaitanawisuti et al. 2011) and Gracilaria and prawns in Hawaii (Nelson et al. 2001). While the main focus is human food, agar extraction for cosmetic applications is also considered. Although most brown algae contain alginic acid, only a few tropical species are sufficiently abundant and have interesting physical characteristics (for example, viscosity) for commercial production: Sargassum, Turbinaria and Padina Adanson (mainly China, Philippines, India and Vietnam; Zubia et al. 2008, Setyawidati et al. 2018b). Brown algae harvested in the warm waters of tropical regions are less interesting from a biochemical perspective for the production of alginates, as was demonstrated in French Polynesia (Zubia et al. 2008, see carbohydrate section). Additionally, these tropical species often have raised concentrations of polyphenols and terpenes that complicate the process of extraction and decrease the quality of the alginate.

\section{Algae for agriculture (compost, fertilizers)}

Globally, many people depend on agriculture for their livelihood. With the aim to meet the ever-increasing demand for food, there is an urgent need to find new ways to increase agricultural resistance to stressors and boost productivity. As an alternative to traditional fertilizers, mainly obtained by agrochemical processes, seaweeds can be used for many agricultural applications, such as bio-fertilizers, soil conditioners, and enhancers because of their high amounts of micro- and macro-nutrients, vitamins, amino acids and growth regulators (Kumar and Sahoo 2011, Arioli et al. 2015). Used as a regular component of agricultural programs, seaweed extracts have the potential to significantly enhance crop gain and resistance to stress and disease in the future (Arioli et al. 2015). Seaweed fertilizers improve not only plant growth and vigor but also soil health by increasing moisture content, growth, and health of soil microbes. Among seaweeds, brown algae are known as being good fertilizers (Levine 2016). Fertilizers made from brown seaweeds contain alginates and sulfated polysaccharides having extensive chelating properties, combining with the metallic ions present in the soil and forming the chelates that absorb moisture, which improves the growth of soil bacteria (Cardozo et al. 2007, Khan et al. 2009). 
Macroalgae and their extracts have a long tradition of being used within French coastal agriculture (Brittany, Normandy, Vendée, Pays Basque) as a soil conditioner to enhance crop productivity, but some examples could also be found in French tropical overseas territories. In French Polynesia, agronomical enrichment trials were conducted using the brown drifting algae S. pacificum and T. ornata as organic additives. The study of Zubia et al. (2014) demonstrated that low supplements of drift algae (1 and 3\%) to plant compost significantly improved maize growth. They noticed a 32-45\%, 74-117\% and 156-196\% increase in stem length, aerial plant dry mass and root dry mass, respectively. This preliminary study suggested that an ecofriendly bio-fertilizer, without any contaminant in the final product, could be made from the drift algae S. pacificum and T. ornata. Agriculture in a tropical country such as French Polynesia, owing to its climatic conditions and its isolated environment, is sensitive to pests. Polynesian farmers need effective tools to fight pathogens and the use of eco-friendly bio-pesticides such as seaweeds has gained momentum (Zubia et al. 2014). Marine algae contain numerous bioactive molecules effective against predators, parasites or diseases. Enhanced resistance to fungal, bacterial and insect attack has been observed with seaweed preparations (Metting et al.1988, Arioli et al. 2015). The oligo- and polysaccharides can act as signals in eliciting plant defenses (Laporte et al. 2007) and several molecules extracted from algae (e.g. terpenoids, phenolic compounds, alkaloids) exhibited strong biological activities, such as anti-bacterial, anti-fungal, anti-helminthic, and nematicidal properties (see reviews in Mayer et al. 2013). Previous studies in India (Sahayaraj and Jeeva 2012) found some insecticidal activities in Sargassum extracts useful for pest management. In the Fiji Islands, large amounts of Gracilaria edulis (S.G. Gmelin) P.C. Silva and Sargassum polycystum C. Agardh biomass occur as coastal drift in Suva, and also in Tuvalu in the lagoon of the main atoll (N'Yeurt and Iese 2015a,b). Such over-abundant seaweeds make good candidates for the production of seaweed fertilizers. In the Caribbean region, some research was carried out in Martinique, on applied uses for massive beachings of Sargassum species. For example, SME Holdex Environnement, a company that produces fertilizers and composts from various sources, obtained financial support from ADEME (Environment and Energy Management Agency) in 2015, to use and valorize Sargassum beachings as biomass for compost in Martinique (Milledge and Harvey 2016). Nevertheless, some precautions were highlighted concerning the richness in arsenic and chlordecone in some beached Sargassum species. Ramkinsoon et al. (2017) found some phyto-elicitor activity (e.g. efficacyin suppressing pathogens from tomato plants) in extracts from three Caribbean species, Sargassum filipendula C. Agardh, Ulva lactuca Linnaeus and Gelidium serrulatum J. Agardh from Trinidad. The authors showed a suppression of infection in cultivated tomato plants and highlighted the interest for local seaweed extracts to create an environmentally friendly, alternative for farmers of the Southern Caribbean to manage diseases. Algas Organics (https://www.algasorganics.com), a SME in Sainte Lucie, has received awards from the Commonwealth for the production of a liquid fertilizer, Algas Total Plant Tonic, which is a Sargassum-based plant product, efficient in the agriculture sector, and sold in St. Lucia, Barbados, Cayman Islands, Trinidad \& Tobago, Canada and the USA.

\section{Algae for animal nutrition}

There is significant potential to use algae as functional feeds for marine and terrestrial farm animals. As with human functional foods or nutraceuticals, feed additives or supplements can offer a range of benefits that are highly relevant to the production of healthier animals. Algae provide trace elements (especially iodine), vitamins, antioxidants and polysaccharides that act as dietary fibers and facilitate digestion (Holdt and Kraan 2011). The effectiveness of algal supplementation varies according to the species of alga and the animals considered. Feed supplements or additives are designed to improve growth rates, taste, color, disease resistance, content of beneficial compounds (e.g. iodine concentration; Holdt and Kraan 2011), or even to reduce the impact of animals on the environment (Kinley et al. 2016).

Many experiments are currently underway in tropical and sub-tropical regions, mainly in the field of aquaculture, for the incorporation of algae (e.g. Asparagopsis, Gracilaria, Hypnea J.V. Lamouroux, Ulva) in shrimp and fish feeds (Nelson et al. 2001, Reverter et al. 2014). These algae or seaweed extracts are used either to replace proteins of animal origin or for their prebiotic or anti-microbial effects, usually in the context of Integrated Multi-Trophic Aquaculture (IMTA) projects. Reverter et al. (2016) studied the effects of local Polynesian plants and the red alga Asparagopsis taxiformis on the orbicular batfish when orally administered. Weight gain and expression of two immune-related genes (i.e. lysozyme $\mathrm{G}$ and transforming growth factor betaTGF- $\beta 1$ ) were studied to analyze immunostimulant activity on orbicular batfish (Platax orbicularis Forsskäl). Asparagopsis taxiformis was the organism displaying the most promising results, promoting a weight gain of $24 \%$ after three weeks of oral administration and significantly increased the relative amount of both Lys $\mathrm{G}$ and TGF- $\beta 1$ transcripts in the kidney and spleen of the fish (Reverter et al. 2016). 


\section{Bioremediation potential of macroalgae}

Seaweeds present a promising resource to be used to remove excess nutrients and various pollutants from aquaculture, agricultural, urban and industrial effluents; they are also a good carbon sink (Chung et al. 2017). Their uses for environmental decontamination are an interesting field of research and development. Different molecules extracted from macroalgae could be used as sorbents, as some species present the capacity of removing toxic pollutants from water and then provide a possible way to manage wastewaters. Altenor et al. (2012) produced different activated carbons, i.e. pyrolysis, physically and chemically activated carbons, from the widely distributed brown seaweed Turbinaria turbinata from Guadeloupe. The authors assessed treatment of methylene blue and demonstrated that the chemically activated carbon was the most efficient existing sorbent to remove it from aqueous solutions. Interestingly, raw and untreated thalli of $T$. turbinata showed a high sorption capacity (Altenor et al. 2012). In tropical regions, the bioremediation capacity of certain algal species (e.g. Caulerpa, Gracilaria and Ulva) is used in aquaculture to purify the waters of shrimp, mollusc or fish basins (Nelson et al. 2001, Chaitanawisuti et al. 2011, Largo et al. 2016). This IMTA approach will therefore be tested in French Polynesia in integrative systems with shrimp and Platax orbicularis. This applied project will be developed to achieve two objectives: effluent purification and improved livestock health. Algae assimilate ammonia, phosphate and $\mathrm{CO}_{2}$ excreted by fish, and convert these wastes into biomass (Li et al. 2016). Purification will minimize the environmental impact of aquaculture activities. Water from the algal production unit can also provide therapeutic benefits to animals, particularly against marine pathogenic bacteria (Pang et al. 2006, Mata et al. 2013). Pathogen management could therefore be achieved both through food but also through the excretion of biocidal molecules directly into water (Schmitt et al. 1995, Mata et al. 2013).

\section{Active ingredients (cosmetics and health)}

\section{Cosmetics sector}

Cosmetics are defined as products developed to be applied, usually externally, to the human body for cleansing, beautifying, and promoting attractiveness (Anunciato and da Rocha Filho 2012). In French Polynesia, valorization of the brown alga Sargassum pacificum in the cosmetics sector was carried out with the cosmetics company
Tikitea (Zubia 2003). This work led to the production of an extract of $S$. pacificum (www.nardev.com/UploadSection/ProdCat-327-1448524951.pdf) which is formulated in several galenics and produced a new range of cosmetics, e.g. monoï or oily macerat, milk, cream, shampoo, shower gel and soaps. This hydroglycolic extract is rich in minerals and contains phenolic compounds, mannitol, sulfated polysaccharides and laminarans. In addition, the skin and eye tolerances of this extract are satisfactory and the levels of heavy metals are negligible (Zubia 2003). A significant antioxidant activity has also been detected in the extract and it is claimed to control skin ageing (Zubia 2003). Additionally, the manufacture of soap containing dried seaweed flakes from T. ornata and/or S. pacificum has been developed. The French Polynesian on-going research program POLYALG is searching for a new candidate for use in cosmetic products. The red algae, Amansia rhodantha (Harvey) J. Agardh (strong antioxidant activity) or Asparagopsis taxiformis (strong antimicrobial activity), could be interesting candidates for the development of new products (Zubia and Mattio 2019, Zubia et al. 2019).

\section{Health}

Seaweeds are rich in several dietary fibers, minerals and vitamins, and also contain numerous proteins/peptides, polyphenols and polyunsaturated fatty acids (omega-3); they are hence strongly recommended as food, as ingredients and as dietary supplements (Holdt and Kraan 2011, Mouritsen et al. 2013, Cardoso et al. 2015, Chapman et al. 2015, Le Rioux et al. 2017). A diet rich in seaweeds or the intake of seaweed extracts have been associated with health benefits, including cardioprotective, neuroprotective and anti-inflammatory effects as well as beneficial impacts on gut function and microbiota or a low incidence of cancers (Zubia et al. 2009, Cian et al. 2015, Liu et al. 2015). Nevertheless, some precautions are necessary before any consumption of wild algae, as some are not safe, since they may be rich in heavy metals and/or arsenic. Rawsonol, a brominated diphenyl methane derivative, extracted from the tropical green alga Avrainvillea rawsonii (Dickie) M. Howe inhibited the activity of 3-hydroxy-3-methylglutaryl coenzyme A (HMG-CoA) reductase, implicated in cholesterol biosynthesis (Carte et al. 1989). Turbinaric acid, isolated from Turbinaria conoides from New Caledonia (Le Lann et al. 2014) is a tris-nor-triterpene (C27), a derivative of squalene, which possesses cytotoxic properties (Kornprobst2014). Studying brown seaweedsin French Polynesia, Bernardini et al. (2018) highlighted interesting pharmacological and health-protecting effects, i.e. anti-proliferative 
and pro-apoptotic activities against two osteo-sarcoma cell lines, for phlorotannins isolated from Padina. Hydroalcoholic extracts from S. pacificum and T. ornata displayed a great antioxidant activity whatever the site and the season (Zubia et al. 2008). In French Polynesia, a screening of biological activities of 26 species of macroalgae has been performed to develop new economic opportunities. The organic extracts have been tested for their enzymatic activity ( $\alpha$-glucosidase and acetylcholinesterase, respectively, involved in diabetes and Alzheimers), and for their cytotoxic activity against melanoma cells (Zubia and Mattio 2019). Regarding enzymatic activities, the highest acetylcholinesterase inhibition was found in Spatoglossum asperum J. Agardh extract and a strong $\alpha$-glucosidase inhibition found in Caulerpa chemnitzia extract. In French Polynesia, $10 \%$ of the population has diabetes (Caisse de prévoyance sociale 2013). This non-communicable disease is the second most important chronic disease in this area after arterial hypertension. Diabetes being a health priority in French Polynesia, the $\alpha$-glucosidase inhibitory activity of seaweeds is of great interest. The cytotoxic activity was the highest in the brown algae Dictyota hamifera Setchell, Chnoospora minima, T. ornata, and Padina boryana Thivy, and in the red alga Amansia rhodanta (Zubia and Mattio 2019, Zubia et al. 2019).

\section{Opportunities offered by tropical macroalgae}

We have listed above the impressive diversity and potentials of macroalgae living in French overseas territories, many of which could be valorized in several industrial sectors. Their uses as a raw material for numerous new applications open up various opportunities and perspectives.

\section{The great chemo-diversity of macroalgae}

Within coastal ecosystems where the biodiversity is often high and interactions between organisms is also important, macroalgae produce various molecules essentially for their defense and communication. This is especially true in coral reefs where interactions between organisms are important, as described earlier in this review. Chemodiversity usually refers to small molecules, as described in La Barre (2014), who explained that the extraordinary biodiversity of coral reefs is maintained by a highly complex chemical network of signaling (offensive or defensive) functions, implying sometimes protective molecules.
The great chemo-diversity found in French tropical overseas macroalgae represents a reservoir of important valueadded molecules with a host of applications. Nevertheless, some issues remain when we want to valorize seaweeds, and notably two of the technological bottlenecks are: (1) wastes generated during processing, which could be overridden by a biorefinery processing approach, adapted to local conditions to maximize the biomass utilization and to lower the waste fractions or prevent any waste materials re-enforcing the circular economy (Torres et al. 2019), and (2) maintaining the supply of biomass as the aquaculture production cost in overseas territories is expensive.

\section{Availability of macroalgal biomass}

Currently, most industries present in French overseas territories use wild stocks of macroalgae. The proliferation of certain species offers new opportunities for the collection of wild species. These blooms are increasing in number, due to climate change and increasing anthropogenic pressures (Fong and Paul 2011, N'Yeurt and Iese 2015a). These algae become bulky waste that is often costly and difficult to manage. One of the solutions considered is industrial valorization, which consists of transforming them into an economic value. This is the case in the South Pacific Ocean, in Tuvalu where islands are facing proliferation and beaching of Sargassum polycystum (N'Yeurt and Iese 2015a, Andréfouët et al. 2017). In Fiji, there is a very rapid proliferation of Gracilaria edulis and S. polycystum (N'Yeurt and Iese 2015a), but also in French Polynesia, where a proliferation of S. pacificum and T. ornata began in the 1990s (Stiger and Payri 1999a,b, Andréfouët et al. 2004, Zubia et al. 2008). On the Caribbean coasts, the problem of mass beaching of Sargassum species has not been solved yet (Smetacek and Zingone 2013, Gower et al. 2013, Johnson et al. 2013, Oyesiku and Egunyomi 2014, Wang and Hu 2016, Maréchal et al. 2017, Ody et al. 2019). Since 2011, the Caribbean has been suffering recurrently from massive strandings of pelagic Sargassum. Huge amounts of Sargassum have been washed onshore, with a negative socio-economic impact on tourism and fishing, and consequences for health. Numerous remote sensing observations around $7^{\circ} \mathrm{N}$, might indicate the presence of a new "Sargasso Sea" in the Tropical North Atlantic (Gower et al. 2013). In 2015 the mean Sargassum summer coverage was estimated to be 20 times higher than that observed for summers between 2000 and 2010 (Wang and $\mathrm{Hu}$ 2016), and the risk of Sargassum washing onshore increased in the Lesser Antilles between 2011 and 2015 (Maréchal et al. 2017). The factors leading to the 
Sargassum blooms remain unknown with regard to both the dynamics and the source regions of these rafts. In the French Antilles, some assays were carried out to valorize the beachings of Sargassum in the Caribbean area, such as the project ECOSAR3, financed by ADEME where researchers have studied the possibility of using stranded biomass of Sargassum for the agricultural sector, to make compost. Other projects, like the project SAVE-C piloted by the first author, have the objective to produce biomaterials with beached Sargassum, as is done in Brittany (Potin, pers comm.). In addition to the cost, which remains high compared to using petrochemical products, a difficulty lies in the installation of a Sargasso Sea collection point. All species of Sargassum have the ability to float more or less along the surface of the ocean, and can proliferate, as demonstrated in other French overseas territories, such as French Polynesia where, for the last 30 years. S. pacificum and T. ornata have bloomed, accompanied by reef degradation (Stiger and Payri 1999a,b, Andréfouët et al. 2004, Stiger and Payri 2005, Martinez et al. 2007, Zubia et al. 2014). These changes have most likely negatively impacted coral recruitment, and both species are now dominant in several sections of reefs in Tahiti and Moorea Islands in French Polynesia. These brown macroalgae are naturally found attached to hard substrata (e.g. dead corals, rubble and pavement), but form free-floating mats after being ripped away by strong wave action. Developing an economy on stranding algae is problematic since this biomass represents an irregular supply and the quality of the resource is also highly variable (Zubia 2003).

\section{Towards the development of farming of seaweeds}

The global market for marine macroalgae was estimated at over US $\$ 10$ billion in 2016 (about 28 million tons of fresh weight per year in 2016; Rebours et al. 2014, FAO 2016). Seaweed farming has grown rapidly over the past 50 years and is now a key sector of the global aquaculture industry. A total of 50 countries produce seaweeds, and Asian countries dominate the market (White and Wilson 2015). Although aquaculture and the large-scale seaweed industry are common practice and a valuable source of income in Asia (FAO 2018, Buschmann et al. 2017, Chung et al. 2017), this is still in its infancy in other parts of the world, particularly in many tropical countries that have a diversity of algae still largely unexploited, as in French tropical overseas territories. This diversity represents important economic, innovation and sustainable development opportunities, particularly for improving the livelihoods of coastal communities. Additionally, climate change mitigation could be achieved through Ocean deforestation using seaweeds (N'Yeurt et al. 2012). In tropical countries, the largest producer in 2016 was Indonesia $(11,631,000$ of tons), followed by the Philippines (1,405,000), Malaysia $(206,000)$ and the United Republic of Tanzania and Zanzibar $(119,000)$ (FAO 2018).

Aquaculture represents a priority economic axis for French Polynesia and the emphasis is placed on the development of new sectors (clams, algae, etc...) in order to develop an island rural aquaculture aiming at a better socio-territorial balance. Algoculture has also been defined as a promising sector in the new master plan for aquaculture. A first project has been set up in Tubuai for the development of a Caulerpa pilot farm. Among the macroalgae consumed, the genus Caulerpa is particularly popular in the Indo-Pacific islands and Asia, and in particular two species C. lentillifera J. Agardh and C. racemosa (Nagappan and Vairappan 2014). Caulerpa culture is still relatively undeveloped in the world today. The current production leaders are the Philippines, Japan and Vietnam. This is a very recent activity in South Pacific islands, most of which is still in the test phase with limited success, but which is developing significantly in the South Pacific islands (Fiji, Samoa and Tonga; Morris et al. 2014, De Gaillande et al. 2017). Concerning the Caribbean area, Litzler (2010) studied the potential of phyco-culture in this geographical area. Indeed, with a coastline of 26,826 $\mathrm{km}$, the Caribbean region has a strong potential for the development of marine micro- and macroalgal cultivation. The Caribbean region has several advantages for facilitating the development of seaweed farming. On the one hand, the geographical proximity to the United States (Florida) and the presence of French territory can allow territorial transfers of competence, technology and investments. On the other hand, the climatic conditions of the intertropical zone are favorable for the growth and massive cultivation of algae: high insolation, stable temperature all year round, high humidity levels.

\section{Towards the development of novel bioenergy and biomaterials}

As world energy demand continues to increase and fossil fuel resources are decreasing, marine seaweeds are becoming an attractive renewable source for producing biogas and bioplastics.

Biogas is a combustible gas resulting from the decomposition of organic matter in an oxygen-deprived environment (anaerobic fermentation). It generally consists of $50-70 \%$ of methane. 
The systems of production - "digesters" - are relatively simple, can be easily built from locally available materials and can operate on a small and large scale almost anywhere (N'Yeurt and Iese 2015a,b). For isolated communities like in overseas French Territories, this technology offers many advantages: reduction of energy poverty (the gas produced free of charge is used for lighting and/or cooking replacing domestic firewood, kerosene etc.), improved sanitation (use of domestic and agricultural waste in digesters), fertilizer production (the residual organic waste can be used as compost), improving the quality of people's lives (especially women's lives: reduction in firewood collection time, no production of cooking smoke). The anaerobic digestion process also makes it possible to significantly reduce greenhouse gas emissions (nearly 70\% compared to the aerobic decomposition). This is a mature technology in Europe (nearly 150 years old), but its application in the Pacific is still in its infancy. Given its potential, several pilot projects are currently underway in the 15 ACP countries of the zone, through the EU GCCA ("European Union Global Climate Change Alliance") led by the University of South Pacific in Fiji. In French Polynesia, a project on biomethane production is being discussed, this project could use $10 \%$ of the Turbinaria ornata washed up on the beaches.

Bioplastic represents bio-sourced matter coming from renewable resources and presenting biodegradable properties that meet standards for biodegradability and compostability in the context of microplastics pollution issues. One such class of biodegradable polymers that has generated much interest is polyhydroxyalkanoates (PHAs), which are linear polyesters formed as cytoplasmic inclusions during the fermentation of sugars or lipids by specific microorganisms (Bera et al. 2015). Bacteria and cyanobacteria are reported to produce polymers utilizing different carbon sources and under various stress conditions (Shrivastav et al. 2010). The widely known macroalgal-derived bioplastic agents are starch and cellulose derivatives from green/red algae, as well as alginate, agar and carrageenan (Hii et al. 2016, Paula et al. 2018, Prabhu et al. 2019). Macroalgal carbohydrates have several unique properties that allow their use in cosmetics and tissue engineering and controlled drug delivery systems as reviewed by Stiger-Pouvreau and Guérard (2018). By processing phycocolloids from brown and red algae, it is possible to obtain novel biomaterials (Rinaudo 2008, Qin 2008) but also for tissue engineering and to encapsulate cells (Kong et al. 2004). In the French Antilles, this type of valorization has been considered by the society Algoback (Saint Malo, France) (http://www.algopack.com), to use the huge quantity of Sargassum that beaches regularly along Caribbean coastal areas. The bioplastics produced from Sargassum beachings are darker and slightly more brittle than conventional plastics (Milledge and Harvey 2016). A French project, SAVE-C, financed by ANR, ADEME, Martinique and Guadeloupe, will begin soon (https://anr.fr/ fileadmin/aap/2019/aap-sargasses-2019.pdf) regrouping several partners from the West Indies, metropolitan France and Mexico in order to develop processes to use Sargassum beachings to manufacture bioplastic bags and some particular composites.

\section{Conclusion}

In this review, we demonstrate that coral reef macroalgae offer a huge and attractive potential for developing new drugs and biomaterials. Studies in chemical ecology (in all the French overseas territories) and the traditional use of macroalgae (such as in French Polynesia for instance) could identify macroalgae that may represent an interesting source of bioactive compounds. An area that is expected to increase in overseas territories is the development of macroalgal farms, especially in French Polynesia. Nevertheless, this great diversity of interesting macroalgae encountered in French tropical overseas territories is fragile because of anthropogenic and natural pressures on these macroalgae (Harley et al. 2006). In many places, all around the world, many seaweeds communities, dominated by large thalli, may disappear or suffer from anthropogenic global climate change, and may be replaced by turf algae or unfortunately coral rubble or sterile substrata if the grazing is intensive (Harley et al. 2006, Johnson 2011, Filbee-Dexter and Wernberg 2018). This phenomenon began in French tropical overseas territories, especially in the Caribbean territories (http:// www.ifrecor.com) and in French Polynesia where large seaweeds, such as large Sargassaceae or Dictyotaceae species are proliferating, threatening the normal algal biodiversity of coral reefs. Moreover, if tropical macroalgal chemo-diversity is well-managed in the future, this economic resource could become the green/blue gold of tomorrow.

Acknowledgments: The authors would like to express here their sincere thanks to Alan T. Critchley who gave us the opportunity to write this review on the tropical macroalgae encountered in French overseas territories. We also sincerely thank A.D.R. N'Yeurt and anonymous reviewers for reviewing earlier versions of this manuscript. 


\section{References}

Altenor, S., M.C. Ncibi, E. Emmanuel and S. Gaspard. 2012. Textural characteristics, physiochemical properties and adsorption efficiencies of Caribbean alga Turbinaria turbinata and its derived carbonaceous materials for water treatment application. Biochem. Engin. J. 67: 35-44.

Amaral-Zettler, L.A., N.B. Dragone, J. Schell, B. Slikas, L.G. Murphy, C.E. Morrall and E.R. Zettler. 2017. Comparative mitochondrial and chloroplast genomics of a genetically distinct form of Sargassum contributing to recent "Golden Tides" in the Western Atlantic. Ecol. Evol. 7: 516-525.

Andréfouët, S., N. Chagnaud, C. Chauvin and C. Kranenburg. 2008. Atlas des récifs coralliens de France Outre-Mer. Centre IRD de Nouméa, Nouméa, Nouvelle-Calédonie. pp 153.

Andréfouët, S., M. Zubia and C. Payri. 2004. Mapping and biomass estimation of the invasive brown algae Turbinaria ornata (Turner) J. Agardh and Sargassum mangarevense (Grunow) Setchell on heterogeneous Tahitian coral reefs using 4-meter resolution IKONOS satellite data. Coral Reefs 23: 26-38.

Andréfouët, S., C. Payri, S. Van Wynsberge. 2017. The timing and the scale of the proliferation of Sargassum polycystum in Funafuti Atoll, Tuvalu. J. Appl. Phycol. 29: 3097-3108.

Angell, A.R., S.F. Angell, R. de Nys and N.A. Paul. 2016a. Seaweed as a protein source for mono-gastric livestock. Trends Food Sci. Technol. 54: 74-84.

Angell, A.R., L. Mata, R. de Nys and N.A. Paul. 2016b. The protein content of seaweeds: a universal nitrogen-to-protein conversion factor of five. J. Appl. Phycol. 28: 511-524.

Anunciato, T.P. and P.A. da Rocha Filho. 2012. Carotenoids and polyphenols in nutricosmetics, nutraceuticals, and cosmeceuticals. J. Cosmet. Dermatol. 11: 51-54.

Arioli, T., S.W. Mattner and P.C. Winberg. 2015. Applications of seaweed extracts in Australian agriculture: past, present and future. J. Appl. Phycol. 27: 2007-2015.

Ballesteros, E. 1994. New records of benthic marine algae from Mauritius (Indian Ocean). Bot. Mar. 37: 537-546.

Barbaroux, O., R. Pérez and J.-P. Dreno. 1964. L'algue rouge Eucheuma spinosum: possibilités d'exploitation et de culture aux Antilles. Science et Pêche 348: 2-9.

Bellard, C., C. Bertelsmeier, P. Leadley, W. Thuiller and F. Courchamp. 2012. Impacts of climate change on the future of biodiversity. Ecol. Lett. 15: 365-377.

Bellwood, D.R., T.P. Hughes, C. Folke and M. Nyström. 2004. Confronting the coral reef crisis. Nature 429: 827-833.

Bera, A., S. Dubey, K. Bhayani, D. Mondal, S. Mishra and P.K. Ghosh. 2015. Microbial synthesis of polyhydroxyalkanoate using seaweed-derived crude levulinic acid as co-nutrient. Int. J. Biol. Macromol. 72: 487-494.

Bernardini G., M. Minetti, G. Polizzotto, M. Biazzo and A. Santucci. 2018. Pro-Apoptotic Activity of French Polynesian Padina pavonica Extract on Human Osteosarcoma Cells. Mar. Drugs 16: 504.

Bickford, D., D.J. Lohman, N.S. Sodhi, D.L. Rahayu, R.H. Meier, K. Winker, K.K. Ingram and I. Das. 2007. Cryptic species as a window on diversity and conservation. Trends Ecol. Evol. 22: 148-155.

Bixler H.J. and H. Porse. 2011. A decade of change in the seaweed hydrocolloids industry. J. Appl. Phycol. 23: 321-335.
Blunt, J.W., B.R. Copp, R.A. Keyzers, M.H. Munro and M.R. Prinsep. 2015. Marine natural products. Nat. Prod. Rep. 32: 116-211.

Bowen, B.W., L.A. Rocha, R.J. Toonen, and S.A. Karl. 2013. The origins of tropical marine biodiversity. Trends Ecol. Evol. 28: 359-366.

Bruno, J.F., I.M. Côté, and L.T. Toth. 2019. Climate change, coral loss, and the curious case of the parrotfish paradigm: why don't marine protected areas improve reef resilience? Ann. Review Mar. Sci. 11: 307-334.

Burkepile, D.E. and M.E. Hay. 2006. Herbivore vs. nutrient control of marine primary producers: context-dependent effects. Ecology 87: 3128-3139.

Buschmann, A.H., C. Camus, J. Infante, A. Neori, A. Israel, M.C. Hernández-González, S.V. Pereda, J.L. Gomez-Pinchetti, A. Golberg, N. Tadmor-Shalev and A.T. Critchley. 2017. Seaweed production: overview of the global state of exploitation, farming and emerging research activity. Eur. J. Phycol. 52: 391-406.

Caisse de prévoyance sociale. 2013. [citation: 09 avril 2019]. http:// www.cps.pf/espace-assure/promotion-de-la-sante/le-diabeteen -polynesie-francaise- 0 .

Cardoso, S.M., O.R. Pereira, A.M. Seca, D.C. Pinto, and A. Silva. 2015. Seaweeds as preventive agents for cardiovascular diseases: from nutrients to functional foods. Mar. Drugs 13: 6838-6865.

Cardozo, K.H.M., T. Guaratini, M.P. Barros, V.R. Falcao, A.P. Tonon, N.P. Lopes, S. Campos, M.A. Torres, A.O. Souza, P. Colepicolo and E. Pinto. 2007. Metabolites from algae with economic impact. Comp. Biochem. Physiol. C-Toxicol. Pharmacol. 146: 60-78.

Carte, B.K., N. Troupe, J.A. Chan, J.W. Westley and D.J. Faulkner. 1989. Rawsonol, an inhibitor of HMG-CoA reductase from the tropical green alga Avrainvillea rawsoni. Phytochem. 28: 2917-2919.

Chaitanawisuti, N., W. Santhaweesuk and S. Kritsanapuntu S. 2011. Performance of the seaweeds Gracilaria salicornia and Caulerpa lentillifera as biofilters in a hatchery scale recirculating aquaculture system for juvenile spotted babylons (Babylonia areolata). Aquacult. internat. 19: 1139-1150.

Chamberlain, A. and T. Pickering. 1998. Post-harvest handling of Caulerpa racemosa for artisanal and export fisheries in Fiji. Fisheries and marine resources. Mar. Studies Prog. Techn. Rep. 3: 90-102.

Chapman, A.S., P. Stevant and W.E. Larssen. 2015. Food or fad? Challenges and opportunities for including seaweeds in a Nordic diet. Bot. Mar. 58: 423-433.

Chopin, T. 2012. Seaweed aquaculture provides diversified products, key ecosystem functions. Part II. Recent evolution of seaweed industry. Glob. Aquac. Adv. 14: 24-27.

Chung, I.K., C.F.A. Sondak and J. Beardall. 2017. The future of seaweed aquaculture in a rapidly changing world. Eur. J. Phycol. 52: 495-505.

Cian, R., S. Drago, F. de Medina and O. Martínez-Augustin. 2015. Proteins and carbohydrates from red seaweeds: evidence for beneficial effects on gut function and microbiota. Mar. drugs 13: 5358-5383.

Cinner, J.E., T.R. McClanahan, T.M. Daw, N.A. Graham, J. Maina, S.K. Wilson and T.P. Hughes. 2009. Linking social and ecological systems to sustain coral reef fisheries. Curr. Biol. 19: 206-212. 
Coastes, A.G. and J.-A. Obando. 1996. The geologic evolution of the Central American isthmus. In: (J.-B.-C. Jackson, A.-F. Budd and A.-G. Coates, eds) Evolution and environment in tropical America. Univ Chicago Press, Chicago, London. pp. 21-56.

Colon, M., P. Guevara, W.H. Gerwick and D. Ballantine. 1987. 5'-hydroxyisoavrainvilleol, a new diphenylmethane derivative from the tropical green alga Avrainvillea nigricans. J. Nat. Prod. 50: 368-374.

Conte, E. and C. Payri. 2002. La consommation des algues en Polynésie française: premiers résultats d'une enquête. Le Journal de la Société des Océanistes 114-115: 165-172.

Conte, E. and C. Payri. 2006. Present day consumption of edible algae in French Polynesia: a study of the survival of pre-European practices. J. Polynesian Soc. 115: 77-93.

Davis, T.A., M. Ramirez, A. Mucci and B. Larsen. 2004. Extraction, isolation and cadmium binding of alginate from Sargassum spp. J. Appl. Phycol. 16: 275-284.

De Clerck, O., M.D. Guiry, F. Leliaert, Y. Samyn and H. Verbruggen. 2013. Algal taxonomy: a road to nowhere? J. Phycol. 49: 215-225.

De Gaillande, C., C. Payri, G. Remoissenet and M. Zubia. 2017. Caulerpa consumption, nutritional value and farming in the Indo-Pacific region. J. Appl. Phycol. 29: 2249-2266.

Demko, A.M., C.D. Amsler, M.E. Hay, J.D. Long, J.B. McClintock, V.J. Paul and E.E. Sotka. 2017. Declines in plant palatability from polar to tropical latitudes depend on herbivore and plant identity. Ecology 98: 2312-2321.

Deslandes, E., P. Pondaven, T. Auperin, C. Roussakis, J. Guezennec, V. Stiger and C. Payri. 2000. Preliminary study of the in vitro antiproliferative effect of a hydroethanolic extract from the subtropical seaweed Turbinaria ornata (Turner) J. Agardh on a human non-small-cell bronchopulmonary carcimona line (NSCLC-N6). J. Appl. Phycol. 12: 257-262.

Dhargalkar, V.K. and N. Pereira. 2005. Seaweed: promising plant of the millennium. Sci. Cult. 71: 60-66.

Diaz-PIferrer, M. 1969. Distribution of the marine benthic flora of the Caribbean Sea. Caribb. J. Sci. 9: 151-178.

Dijoux, L., F. Viard and C. Payri. 2014. The more we search, the more we find: discovery of a new lineage and a new species complex in the genus Asparagopsis. PLoS One 9: e103826.

Dixit, D.C., C.R.K. Reddy, N. Balar, P. Suthar, T. Gajaria and D.K. Gadhavi. 2018. Assessment of the nutritive, biochemical, antioxidant and antibacterial potential of eight tropical macro algae along Kachchh coast, India as human food supplements. J. Aquat. Food Prod Technol. 27: 61-79.

Duarte, M.E., J.P. Cauduro, D.G. Noseda, M.D. Noseda, A.G. Gonçalves, C.A. Pujol, E.B. Damonte and A.S. Cerezo. 2004. The structure of the agaran sulfate from Acanthophora spicifera (Rhodomelaceae, Ceramiales) and its antiviral activity. Relation between structure and antiviral activity in agarans. Carbohyd. Res. 339: 335-347.

Espinosa-Avalos, J. 1994. Seaweed as food in the Caribbean. Appl. Phycol. Forum 11: 13.

Evans, R.D., S.K. Wilson, S.N. Field and J.A.Y. Moore. 2014. Importance of macroalgal fields as coral reef fish nursery habitat in north-west Australia. Mar. Biol. 161: 599-607.

FAO. 2016. The State of World Fisheries and Aquaculture 2016. Contributing to food security and nutrition for all. Rome. pp. 200.

FAO. 2018. The State of World Fisheries and Aquaculture 2016. Achieve the objectives of Sustainable development. Rome. pp. 237.
Ferrario, F., M.W. Beck, C.D. Storlazzi, F. Micheli, C.C. Shepard and L. Airoldi. 2014. The effectiveness of coral reefs for coastal hazard risk reduction and adaptation. Nature comm. 5: 3794.

Fiehn, 0. 2002. Metabolomics - the link between genotypes and phenotypes. Plant Mol. Biol. 48: 155-171.

Filbee-Dexter, K. and T. Wernberg. 2018. Rise of turfs: a new battlefront for globally declining kelp forests. BioScience 68: 64-76.

Fleurence, J., M. Morançais, P. Decottignies, V. Turpin, M. Munier, N. Garcia-Bueno and P. Jaouen. 2012. What are the prospects for using seaweed in human nutrition and for marine animals raised through aquaculture? Trends Food Sci. Technol. 27: 57-61.

Fong, P. and V.J. Paul. 2011. Coral reef algae. In: (Z. Dubinsky and N. Stambler, eds) Coral reefs: an ecosystem in transition. Springer, New York. pp. 241-272.

Gager, L., F. Lalegerie, S. Connan and V. Stiger-Pouvreau. 2019. Chapter 16. Marine algal-derived phenolic compounds and their biological activities for medicine and cosmetic applications. In: (G. Rajauria and Y.V. Yuan, eds) Recent Advances in micro and macroalgal processing: food and health perspectives. J. Wiley \& Sons, Inc., Hoboken, NJ, USA.

García-Rodríguez, L.D., R. Riosmena-Rodríguez, S.Y. Kim, M. LópezMeyer, J. Orduña-Rojas, J.M. López-Vivas and S.M. Boo. 2013. Recent introduction of Gracilaria parvispora (Gracilariales, Rhodophyta) in Baja California, Mexico. Bot. Mar. 56: 143-150.

Gardes, L. and B. Salvat. 2008. Les récifs coralliens de la France d'Outre-Mer: rétrospective des évolutions enregistrées par les réseaux de surveillance de l'état de santé de ces écosystèmes diversifiés et fragiles. Revue d'écologie.

Gargominy, O., F. Michel and S. Tercerie. 2017. Construction du référentiel taxonomique commun TAXREF, socle pour la connaissance et l'échange de données. In: Séminaire Inter-opérabilité des systèmes d'information sur l'eau (INSIDE 2017).

Gaubert, J., S. Greff, O. Thomas and C.E. Payri. 2019. Metabolomic variability of four macroalgal species of the genus Lobophora using diverse approaches. Phytochem. 162: 165-172.

Glenn, E.P., D. Moore, J.J. Brown, R. Tanner, K. Fitzsimmons, M. Akutigawa and S. Napolean. 1998. A sustainable culture system for Gracilaria parvispora (Rhodophyta) using sporelings, reef growout and floating cages in Hawaii. Aquaculture 165: 221-232.

Gosch, B.J., M. Magnusson, N.A. Paul and R. de Nys. 2012. Total lipid and fatty acid composition of seaweeds for the selection of species for oil-based biofuel and bioproducts. Gcb Bioenergy 4: 919-930.

Govindaraghavan, S., J.R. Hennell and N.J. Sucher. 2012. From classical taxonomy to genome and metabolome: towards comprehensive quality standards for medicinal herb raw materials and extracts. Fitoterapia 83: 979-988.

Gower, J., E. Young and S. King. 2013. Satellite images suggest a new Sargassum source region in 2011. Remote Sens. Lett. 4: 764-773.

Greff, S., M. Zubia, G. Genta-Jouve, L. Massi, T. Perez and O.P. Thomas. 2014. Mahorones, highly brominated cyclopentenones from the red alga Asparagopsis taxiformis. J. Nat. Prod. 77: 1150-1155.

Greff, S., M. Zubia, C. Payri, O.P. Thomas and T. Perez. 2017. Chemogeography of the red macroalgae Asparagopsis: metabolomics, bioactivity, and relation to invasiveness. Metabolomics 13: 33. 
Guiry, M.D. and G.M. Guiry. 2019. AlgaeBase. World-wide electronic publication, National University of Ireland, Galway. http://www. algaebase.org; searched on 26 February 2019.

Hamann, M.T., C.S. Otto, P.J. Scheuer and D.C. Dunbar. 1996. Kahalalides: bioactive peptides from a marine mollusk Elysia rufescens and its algal diet Bryopsis sp. J. Org. Chem. 61: 6594-6600.

Hamed, I., F. Özogul, Y. Özogul and J.M. Regenstein. 2015. Marine bioactive compounds and their health benefits: a review. Comprehensive Rev. Food Sci. Food Safety 14: 446-465.

Harley, C.D., A. Randall Hughes, K.M. Hultgren, B.G. Miner, C.J. Sorte, C.S. Thornber, L.F. Rodriguez, L. Tomanek and S.L. Williams. 2006. The impacts of climate change in coastal marine systems. Ecol. Letters 9: 228-241.

Harley, C.D.G., K.M. Anderson, K.W. Demes, J.P. Jorve, R.L. Kordas, T.A. Coyle. 2012. Effects of climate change on global seaweed communities. J. Phycol. 48: 1064-1078.

Hay, M.E. 1997. The ecology and evolution of seaweed-herbivore interactions on coral reefs. Coral Reefs 16: 67-76.

Heo, S.J. and Y.J. Jeon. 2009. Protective effect of fucoxanthin isolated from Sargassum siliquastrum on UV-B induced cell damage. J. Photochem. Photobiol. B: Biol. 95: 101-107.

Hii, S.L., J. Lim, W.T. Ong, C.L. Wong. 2016. Agar from Malaysian red seaweed as potential material for synthesis of bioplastic film. J. Eng. Sci. Technol. 7: 1-15.

Hoegh-Guldberg, O., P.J. Mumby, A.J. Hooten, R.S. Steneck, P. Greenfield, E. Gomez, C.D. Harvell, P.F. Sale, A.J. Edwards, K. Caldeira, N. Knowlton, C.M. Eakin, R. Iglesias-Prieto, N. Muthiga, R.H. Bradbury, A. Dubi and M.E. Hatziolos. 2007. Coral reefs under rapid climate change and ocean acidification. Science 318: 1737-1742.

Holdt, S.L. and S. Kraan. 2011. Bioactive compounds in seaweed: functional food applications and legislation. J. Appl. Phycol. 23: 543-597.

Hughes, T.P., M.J. Rodrigues, D.R. Bellwood, D. Ceccarelli, O. HoeghGuldberg, L. McCook, N. Moltschaniwsky, M.S. Pratchett, R.S. Steneck and B. Willis. 2007. Phase shifts, herbivory, and the resilience of coral reefs to climate change. Curr. Biol. 17: 360-365.

Jégou, C., G. Culioli, N. Kervarec, G. Simon and V. Stiger-Pouvreau. 2010. LC/ESI-MS ${ }^{n}$ and ${ }^{1}$ H HR-MAS NMR analytical methods as useful taxonomical tools within the genus Cystoseira C. Agardh (Fucales; Phaeophyceae). Talanta 83: 613-622.

Jégou, C., G. Culioli, V. Stiger-Pouvreau. 2012. Meroditerpene from Cystoseira nodicaulis and its taxonomic significance. Bioch. Syst. Ecol. 44: 202-204.

Jesus, A., M. Correia-da-Silva, C. Afonso, M. Pinto, and H. Cidade. 2019. Isolation and potential biological applications of haloaryl secondary metabolites from macroalgae. Mar. drugs 17: 73.

Johnson, M.T. 2011. Evolutionary ecology of plant defences against herbivores. Funct. Ecol. 25: 305-311.

Johnson, C.C., E.J. Barron, E.G. Kauffman, M.A. Arthur, P.J. Fawcett and M.K. Yasuda. 1996. Middle Cretaceous reef collapse linked to ocean heat transport. Geology 24: 376-380.

Johnson, D.R., S.K. Dong, J.S. Francks, P. Moreno and G. SanchezRubio. 2013. The Sargassum invasion of the eastern Caribbean and dynamics of the equatorial North Atlantic. Proc. 65th Gulf and Carib. Fish. Inst. 65: 102-103.

Jothisaraswathi, S., B. Babu and R. Rengasamy. 2006. Seasonal studies on alginate and its composition. II: Turbinaria conoides (J.Ag.) Kütz. (Fucales, Phaeophyceae). J. Appl. Phycol. 18: 161.
Khan, W., U.P. Rayirath, S. Subramanian, M.N. Jithesh, P. Rayorath, D.M. Hodges, A.T. Critchley, J.S. Craigie, J. Norrie and B. Prithiviraj. 2009. Seaweed extracts as biostimulants of plant growth and development. J. Plant Growth Regul. 28: 386-399.

Kinley, R.D., R. de Nys, M.J. Vucko, L. Machado and N.W. Tomkins. 2016. The red macroalgae Asparagopsis taxiformis is a potent natural antimethanogenic that reduces methane production during in vitro fermentation with rumen fluid. Anim. Prod. Sci. 56: 282-289.

Koch, M., G. Bowes, C. Ross and X.H. Zhang. 2013. Climate change and ocean acidification effects on seagrasses and marine macroalgae. Glob. Change Biol. 19: 103-132.

Kooistra, W.H., E.G. Coppejans and C. Payri. 2002. Molecular systematics, historical ecology, and phylogeography of Halimeda (Bryopsidales). Mol. Phylogen. Evol. 24: 121-138.

Kong, H.J., D. Kaigler, K. Kim and D.J. Mooney. 2004. Controlling rigidity and degradation of alginate hydrogels via molecular weight distribution. Biomacromol. 5: 1720-1727.

Kornprobst, J.M. 2014. Encyclopedia of marine natural products, 3, Protostomes and deuterostomes. 2nd edition. Wiley-VCH, Weinheim.

Kumar, G. and D. Sahoo. 2011. Effect of seaweed liquid extract on growth and yield of Triticum aestivum var. Pusa Gold. J. Appl. Phycol. 23: 251-255.

Kumar, M., U. Kuzhiumparambil, M. Pernice, Z. Jiang and P.J. Ralph. 2016. Metabolomics: an emerging frontier of systems biology in marine macrophytes. Algal Res. 16: 76-92.

Kumari, P., M. Kumar, V. Gupta, C.R.K. Reddy and B. Jha. 2010. Tropical marine macroalgae as potential sources of nutritionally important PUFAs. Food Chem. 120: 749-757.

Kurth, C., M. Welling and G. Pohnert. 2015. Sulfated phenolic acids from Dasycladales siphonous green algae. Phytochem. 117: 417-423.

La Barre, S. 2014. Marine biodiversity and chemodiversity - the treasure troves of the future. In: (Oscar Grillo, ed) Biodiversity - The Dynamic Balance of the Planet. InTech, Rijeka, Croatai. pp. 1-26. ISBN: 978-953-51-1315-7.

Lalegerie, F., S. Lajini, G. Bedoux, L. Taupin, V. Stiger-Pouvreau and S. Connan. 2019. Photoprotective compounds in red macroalgae from Brittany: a large diversity in mycosporine-like amino acids (MAAs). Mar. Env. Res. 147: 37-48.

Laporte, D., J. Vera, N.P. Chandía, E.A. Zúñiga, E.B. Matsuhiro and A. Moenne. 2007. Structurally unrelated algal oligosaccharides differentially stimulate growth and defense against tobacco mosaic virus in tobacco plants. J. Appl. Phycol. 19: 79-88.

Largo, D.B., A.G. Diola and M.S. Marababol. 2016. Development of an integrated multi-trophic aquaculture (IMTA) system for tropical marine species in southern Cebu, Central Philippines. Aquacult. Rep. 3: 67-76.

Larsen, B., D.M.S.A. Salem, M.A.E. Sallam, M.M. Mishrikey and A.I. Beltagy. 2003. Characterization of the alginates from algae harvested at the Egyptian Red Sea coast. Carbohydr. Res. 338: 2325-2336.

Le Bras, Q., M. Lesueur, S. Lucas and S. Gouin. 2015. Etude du marché français des algues alimentaires. Panorama de la distribution en magasins. Programme IDEALG Phase 2: Les publications du Pôle halieutique AGROCAMPUS OUEST 36: pp. 42.

Le Lann, K., N. Kervarec, C.E. Payri, E. Deslandes and V. StigerPouvreau. 2008. Discrimination of allied species within the 
genus Turbinaria (Fucales, Phaeophyceae) using HRMAS NMR spectroscopy. Talanta 74: 1079-1083.

Le Lann, K., C. Ferret, E. VanMee, C. Spagnol, M. Lhuillery and V. Stiger-Pouvreau. 2012. Total phenolic, size-fractionated phenolics and fucoxanthin content of tropical Sargassaceae (Fucales, Phaeophyceae) from the South Pacific Ocean: spatial and specific variability. Phycol. Res. 60:37-50.

Le Lann, K., E. Kraffe, N. Kervarec, S. Cérantola, C.E. Payri and V. Stiger-Pouvreau. 2014. Isolation of turbinaric acid as a chemomarker of Turbinaria conoides (J. Agardh) Kützing from South Pacific islands. J. Phycol. 50: 1048-1057.

Le Rioux, L., L. Beaulieu and S.L. Turgeon. 2017. Seaweeds: a traditional ingredients for new gastronomic sensation. Food Hydrocoll. 68: 255-265.

Levine, I. 2016. Algae: a way of life and health. In: (J. Fleurence and I. Levine, eds) Seaweed in Health and Disease Prevention. Academic Press, Elsevier. pp. 1-5.

Li, Y., D. Li, Y. Rao, Y. Zhao and M. Wu. 2016. Superior $\mathrm{CO}_{2}, \mathrm{CH}_{4}$, and $\mathrm{H}_{2}$ uptakes over ultrahigh-surface-area carbon spheres prepared from sustainable biomass-derived char by $\mathrm{CO}_{2}$ activation. Carbon 105: 454-462.

Littler, M.M., D.S. Littler and P.R. Taylor. 1983. Evolutionary strategies in a tropical barrier reef system: functional-form groups of marine macroalgae. J. Phycol. 19: 229-237.

Litzler, S. 2010. Les algues sont-elles une ressource marine à exploiter pour développer durablement l'espace caribéen ? Études caribéennes 15.

Liu, J.H., S. Kandasamy, J.Z. Zhang, C.W. Kirby, T. Karakach, J. Hafting, A.T. Critchley, F. Evans and B. Prithiviraj. 2015. Prebiotic effects of diet supplemented with the cultivated red seaweed Chondrus crispus or with fructo-oligo-saccharide on host immunity, colonic microbiota and gut microbial metabolites. BMC Complement. Altern. Med. 15: 279.

Loiseau, N., C.E. Payri, L. Mattio, S. Andréfouët, M. Grellier and M. Zubia. 2019. Functional convergence in macroalgal assemblages of isolated coral reefs in the Mozambique Channel. Mar. Biol. 166: 27.

Lucena, A.M.M., C.R.M. Souza, J.T. Jales, P.M.M. Guedes, G.E.C. de Miranda, A.M.A. de Moura, J.X. Araújo-Júnior, G.J. Nasciemento, K.C. Scortecci, B.V.O. Santos and J.T. Souto. 2018. The Bisindole Alkaloid Caulerpin, from Seaweeds of the Genus Caulerpa, Attenuated Colon Damage in Murine Colitis Model. Mar. Drugs 16: 318-336.

MacArtain, P., C.I. Gill, M. Brooks, R. Campbell and I.R. Rowland. 2007. Nutritional value of edible seaweeds. Nutr. Rev. 65: 535-543.

Mancini-Filhoa, J., A.V. Novoa, A.E.B. González, E.R. de AndradeWartha, A. Mara de 0 e Silva, J.R. Pinto and D.A. Portari Mancini. 2009. Free phenolic acids from the seaweed Halimeda monile with antioxidant effect protecting against liver injury. Z. Naturforsch. C 64: 657-663.

Maréchal, J.-P., C. Hellio and C. Hu. 2017. A simple, fast, and reliable method to predict Sargassum washing ashore in the Lesser Antilles. Remote Sens. Appl.: Soc. Environ. 5: 54-63.

MarinLit. 2019. MarinLit: a database of the marine natural products literatura. Royal Society of Chemistry. http://pubs.rsc.org/ marinlit.

Martinez, E., K. Maamaatuaiahutapu, C.E. Payri and A. Ganachaud. 2007. Turbinaria ornata invasion in the Tuamotu Archipelago, French Polynesia: ocean drift connectivity. Coral Reefs 26: 79-86.
Maschek, J.A. and B.J. Baker. 2008. The chemistry of algal secondary metabolism. In: (D.C.D. Amsler, ed) Algal Chemical Ecology. Springer Berlin Heidelberg. pp. 1-24.

Mata, L., E. Wright, L. Owens, N. Paul and R. de Nys. 2013. Watersoluble natural products from seaweed have limited potential in controlling bacterial pathogens in fish aquaculture. J. Appl. Phycol. 25: 1963-1973.

Matanjun, P., S. Mohamed, N.M. Mustapha and K. Muhammad. 2009. Nutrient content of tropical edible seaweeds, Eucheuma cottonii, Caulerpa lentillifera and Sargassum polycystum. J. Appl. Phycol. 21: 75-80.

Mattio, L. and C. Payri. 2011. 190 years of Sargassum taxonomy, facing the advent of DNA phylogenies. Bot. Rev. 77: 31-70.

Mattio, L., C.E. Payri and V. Stiger-Pouvreau. 2008. Taxonomic revision of the genus Sargassum (Fucales, Phaeophyceae) from French Polynesia based on morphological and molecular analyses. J. Phycol. 44: 1541-1555.

Mattio, L., M. Zubia, G.W. Maneveldt, R.J. Anderson, J.J. Bolton, C. de Gaillande, O. de Clerck and C.E. Payri. 2016. Marine flora of the Iles Eparses (Scattered Islands): a longitudinal transect through the Mozambique Channel. Acta Oecol. 72: 33-40.

Máximo, P., L. Ferreira, P. Branco, P. Lima and A. Lourenço. 2018. Secondary metabolites and biological activity of Invasive Macroalgae of Southern Europe. Mar. Drugs 16: 265.

Mayer, A., A. Rodríguez, O. Taglialatela-Scafati and N. Fusetani. 2013. Marine pharmacology in 2009-2011: marine compounds with antibacterial, antidiabetic, antifungal, anti-inflammatory, antiprotozoal, antituberculosis, and antiviral activities; affecting the immune and nervous systems, and other miscellaneous mechanisms of action. Mar. Drugs 11: 2510-2573.

McHugh, D.J. 1987. Production, properties and uses of alginates. Production and Utilization of Products from Commercial Seaweeds. FAO. Fish. Tech. Pap. 288: 58-115.

Metting, B., W.R. Rayburn and P.A. Reynaud. 1988. Algae and agriculture. In: Algae and human affairs. Cambridge University Press, Cambridge, UK. pp. 335-370.

Milledge, J. and P. Harvey. 2016. Golden Tides: Problem or golden opportunity? The valorisation of Sargassum from beach inundations. J. Mar. Sci. Eng. 4: 60-79.

Minghou, J., W. Yujun, X. Zuhong and G. Yucai. 1984. Studies on the $\mathrm{M}: \mathrm{G}$ ratios in alginate. In: Eleventh International Seaweed Symposium. Springer, Dordrecht. pp. 554-556.

Moberg, F. and C. Folke. 1999. Ecological goods and services of coral reef ecosystems. Ecol. Econ. 29: 215-233.

Mohamed, S., S.N. Hashim and A. Rahman. 2012. Seaweeds: a sustainable functional food for complementary and alternative therapy. Trends Food Sci. Technol. 23: 83-96.

Montaggioni, L.F. and C.J.R. Braithwaite. 2009. Chapter five patterns of carbonate production and deposition on Reefs. Develop. Mar. Geol. 5: 171-222.

Moritz, C., J. Vii, W. Lee Long, J. Tamelander, A. Thomassin and S. Planes, eds. 2018. Status and trends of coral reefs of the Pacific. Global Coral Reef Monitoring Network. pp 218.

Morris, C., S. Bala, G.R. South, J. Lako, M. Lober and T. Simos. 2014. Supply chain and marketing of sea grapes, Caulerpa racemosa (Forsskal) J. Agardh (Chlorophyta: Caulerpaceae) in Fiji, Samoa and Tonga. J. Appl. Phycol. 26:783-789.

Mouritsen, O.G., C. Dawczynski, L. Duelund, G. Jahreis, W. Vetter and S. Scgröder. 2013. On the human consumption of the red 
seaweed dulse (Palmaria palmata (L.) Weber \& Mohr). J. Appl. Phycol. 25: 1777-1791.

Mumby, P.J. and A.R. Harborne. 2010. Marine reserves enhance the recovery of corals on Caribbean reefs. PLoS One 5: e8657.

Nagappan, T. and C.S. Vairappan. 2014. Nutritional and bioactive properties of three edible species of green algae genus Caulerpa (Caulerpaceae). J. Appl. Phycol. 26: 1019-1027.

Nelson, S.G., E.P. Glenn, J. Conn, D. Moore, T. Walsh and M. Akutagawa. 2001. Cultivation of Gracilaria parvispora (Rhodophyta) in shrimp-farm effluent ditches and floating cages in Hawaii: a two-phase polyculture system. Aquaculture 193: 239-248.

Nelson, S.G., E.P. Glenn, D. Moore and B. Ambrose. 2009. Growth and distribution of the macroalgae Gracilaria salicornia and G. parvispora (Rhodophyta) established from aquaculture introductions at Moloka'i, Hawai'i. Pacific Sci. 63: 383-397.

Newton, K., I.M. Côté, G.M. Pilling, S. Jennings and N.K. Dulvy. 2007. Current and future sustainability of Island coral reef fisheries. Curr. Biol. 17: 655-658.

Novoa, A.V., E.R. Andrade-Wartha, A.F. Linares, M.I. Genovese, A.E.B. González, P. Vuorela, A. Costa and J. Mancini-Filho. 2011. Antioxidant activity and possible bioactive components in hydrophilic and lipophilic fractions from the seaweed Halimeda incrassata. Rev. Bras. Farmacogn. 21: 53-57.

N'Yeurt, A.D., and C.E. Payri. 2004. A preliminary annotated checklist of the marine algae and seagrasses of the Wallis Islands (French Overseas Territory of Wallis and Futuna), South Pacific. Aust. Syst. Bot. 17: 367-397.

N'Yeurt, A.D.R. and C.E. Payri. 2006. Marine algal flora of French Polynesia. I. Phaeophyceae (Ochrophyta, brown algae). Crypt. Algol. 27: 111-152.

N'Yeurt, A.D.R. and C.E. Payri. 2007. Marine algal flora of French Polynesia. II. Chlorophyceae (green algae). Crypt.Algol. 28: 3-88.

N'Yeurt, A.D.R. and C.E. Payri. 2010. Marine algal flora of French Polynesia III. Rhodophyta, with additions to the Phaeophyceae and Chlorophyta. Crypt.Algol. 31: 3-196.

N'Yeurt, A.D.R. and V. lese. 2015a. Marine plants as a sustainable source of agrifertilizers for Small Island Developing States (SIDS). In: (W.G. Ganpat and W.A. Isaac, eds) Impacts of Climate Change on Food Security in Small Island Developing States. IGI Global, Hershey, Pennsylvania. pp. 280-311. (ISBN: 978-1-4666-6501-9).

N'Yeurt, A.D.R. and V. lese. 2015b. The proliferating brown alga Sargassum polycystum in Tuvalu, South Pacific: assessment of the bloom and applications to local agriculture and sustainable energy. J. App. Phycol. 27: 2037-2045.

N'Yeurt, A.D.R., D.P. Chynoweth, M.E. Capron, J.R. Stewart and M.A. Hasan. 2012. Negative Carbon via Ocean Afforestation. Process Saf. Environ. 90: 467-474.

O'Doherty, D.C. and A.R. Sherwood. 2007. Genetic population structure of the Hawaiian alien invasive seaweed Acanthophora spicifera (Rhodophyta) as revealed by DNA sequencing and ISSR Analyses1. Pacific Sci. 61: 223-234.

Ody A., T. Thibaut, L. Berline, T. Changeux, J.-M. André, C. Chevalier, A. Blanfuné, J. Blanchot, S. Ruitton, V. Stiger-Pouvreau, S. Connan, J. Grelet, D. Aurelle, M. Guéné, H. Bataille, C. Bachelier, D. Guillemain, N. Schmidt, V. Fauvelle, S. Guasco and F. Ménard. 2019. From In Situ to satellite observations of pelagic Sargassum distribution and aggregation in the Tropical North Atlantic Ocean. PLoS One 14: e0222584.

Oyesiku, 0.0. and A. Egunyomi. 2014. Identification and chemical studies of pelagic masses of Sargassum natans (Linnaeus)
Gaillon and S. fluitans (Borgessen) Borgesen (brown algae), found offshore in Ondo State, Nigeria. Afr. J. Biotech. 13: 1188-1193.

Pal, A., M. Kamthania and A. Kumar. 2014. Bioactive compounds and properties of seaweeds-a review. Open Access Libr. J. 1: e752.

Pang, S.J., T. Xiao and Y. Bao. 2006. Dynamic changes of total bacteria and Vibrio in an integrated seaweed-abalone culture system. Aquaculture 252: 289-297.

Parent-Massin, D. 1996. Evaluation of the toxicological risk to humans of caulerpenyne using human hematopoietic progenitors, melanocytes, and keratinocytes in culture. J. Toxicol. Env. Health Part A 47: 47-59.

Paul, V.J., M.M. Littler, D.S. Littler and W. Fenical. 1987. Evidence for chemical defense in tropical green alga Caulerpa ashmeadii (Caulerpaceae: Chlorophyta): isolation of new bioactive sesquiterpenoids. J. Chem. Ecol. 13: 1171-1185.

Paula (de), F.C., C.B. de Paula and J. Contiero. 2018. Prospective biodegradable plastics from biomass conversion processes. Biofuels: State of Development. doi: 10.5772/intechopen.75111.

Payri, C.E. 1985. Contribution à la connaissance de la flore marine benthique de l'île de La Réunion (Archipel des Mascareignes, Océan Indien). Proc. 5th Int. Coral Reef Congr. 6: 635-640.

Payri, C. 2007. Revised checklist of marine algae (Chlorophyta, Rhodophyta and Ochrophyta) and seagrasses (Marine Angiosperma) of New Caledonia. In: (C.E. Payri and R. Richer de Forges, eds) Compendium of marine species from New Caledonia. IRD-Nouméa, Documents scientifiques et techniques, II, 2e ed. pp. 95-112.

Payri, C.E. (Dir.). 2018. Nouvelle Calédonie, archipel de corail. IRD Editions/Solaris, Marseille/Nouméa, 288p.

Payri, C., A.D.R. N'Yeurt and J. Orempüller. 2000. Algae of French Polynesia -Algues de Polynésie française. Tahiti. Edition Au Vent des îles.

Payri, C.E., J.-L. Menou, and A.D.R.N. Yeurt. 2009. Clipperton: La flore marine du complexe récifal et quelques aspects de la biodiversité et de la géomorphologie de l'île. Muséum National d'Histoire Naturelle and IRD Editions.

Pereira, D.C., T.G. Trigueiro, P. Colepicolo and E. Marinho-Soriano. 2012. Seasonal changes in the pigment composition of natural population of Gracilaria domingensis (Gracilariales, Rhodophyta). Rev. Bras. Farmacogn. 22: 874-880.

Perez, R. 1992. Culture des algues marines dans le monde. Ifremer. Pérez-Rodríguez, E., J. Aguilera and F.L. Figueroa. 2003. Tissular localization of coumarins in the green alga Dasycladus vermicularis (Scopoli) Krasser: a photoprotective role? J. Exp. Bot. 54: 1093-1100.

Pesando, D., R. Lemee, C. Ferrua, P. Amade and J.-P. Girard. 1996. Effects of caulerpenyne, the major toxin from Caulerpa taxifolia on mechanisms related to sea urchin egg cleavage. Aquat. Toxicol. 35: 139-155.

Plouguerné, E., P. Georgantea, E. Ioannou, C. Vagias, V. Roussis, C. Hellio, E. Kraffe and V. Stiger-Pouvreau. 2010. Anti-microfouling activity of lipidic metabolites from the invasive brown alga Sargassum muticum (Yendo) Fensholt. Mar. Biotechnol. 12: 52-61.

Prabhu, M., A. Chemodanov, R. Gottlieb, M. Kazir, O. Nahor, M. Gozin, A. Israel, Y.D. Livney and A. Golberg. 2019. Starch from the sea: the green macroalga Ulva ohnoi as a potential source for sustainable starch production in the marine biorefinery. Algal Res. 37: 215-227. 
Qin, Y. 2008. Alginate fibres: an overview of the production processes and applications in wound management. Polym. Int. 57: 171-180.

Ramkinsoon, A., A. Ramsubhag and J. Jayaraman. 2017. Phytoelicitor activity of three Caribbean seaweed species on suppression of pathogenic infections in tomato plants. J. Appl. Phycol. 29: 3235-3244.

Rasher, D.B. and M.E. Hay. 2010. Chemically rich seaweeds poison corals when not controlled by herbivores. Proc. Natl. Acad. Sci. 107: 9683-9688.

Rasher, D.B. and M.E. Hay. 2014. Competition induces allelopathy but suppresses growth and anti-herbivore defence in a chemically rich seaweed. Proc. R. Soc. B 281: 20132615 (1-9).

Rebours, C., E. Marinho-Soriano, J.A. Zertuche-González, L. Hayashi, J.A. Vásquez, P. Kradolfer, G. Soriano, R. Ugarte, M.H. Abreu, I. Bay-Larsen, G. Hovelsrud, R. Rødven and D. Robledo. 2014. Seaweeds: an opportunity for wealth and sustainable livelihood for coastal communities. J. Appl. Phycol. 26: 1939-1951.

Reverter, M., N. Bontemps, D. Lecchini, B. Banaigs and P. Sasal. 2014. Use of plant extracts in fish aquaculture as an alternative to chemotherapy: current status and future perspectives. Aquaculture 433: 50-61.

Reverter, M., D. Saulnier, R. David, A. Bardon-Albaret, C. Belliard, N. Tapissier-Bontemps, D. Lecchini and P. Sasal. 2016. Effects of local Polynesian plants and algae on growth and expression of two immune-related genes in orbicular batfish (Platax orbicularis). Fish Shellfish Immunol. 58: 82-88.

Rinaudo, M. 2008. Main properties and current applications of some polysaccharides as biomaterials. Polym. Int. 57: 397-430.

Rodríguez-Prieto, C., G. Michanek and C. Ivon. 1999. Benthic marine algae from Martinique (Lesser Antilles). Scientia Gerudensis 24: 79-86.

Rohfritsch, A., C. Payri, V. Stiger and F. Bonhomme. 2007. Molecular and morphological relationships between two closely related species, Turbinaria ornata and T. conoides (Sargassaceae, Phaeophyceae). Biochem. Syst. Ecol. 35: 91-98.

Rohfritsch, A., C. Payri, V. Stiger and F. Bonhomme. 2010. Habitatrelated allelic variation revealed by an anonymous DNA locus in the reef dwelling Turbinaria ornata (Fucales, Phaeophyceae). Bot. Mar. 53: 189-192.

Sahayaraj, K. and Y.M. Jeeva. 2012. Nymphicidal and ovipositional efficacy of seaweed Sargassum tenerrimum (J. agardh) against Dysdercus cingulatus (Fab.) (Pyrrhocoridae). Chilean J. Agricult. Res. 72: 152-156.

Sánchez-Machado, D.I., J. López-Cervantes, J. Lopez-Hernandez and P. Paseiro-Losada. 2004. Fatty acids, total lipid, protein and ash contents of processed edible seaweeds. Food Chem. 85: 439-444.

Saunders, G.W. and K.V. Lehmkuhl. 2005. Molecular divergence and morphological diversity among four cryptic species of Plocamium (Plocamiales, Florideophyceae) in northern Europe. Eur. J. Phycol. 40: 293-312.

Schell, J.M., D.S. Goodwin and A.N.S. Siuda. 2015. Recent Sargassum Inundation Events in the Caribbean. Oceanography 28: 8-10.

Schmitt, T.M., M.E. Hay and N. Lindquist. 1995. Antifouling and herbivore deterrent roles of seaweed secondary metabolites: constraints on chemically-mediated coevolution. Ecology 76 : 107-123.
Setyawidati, N.A.R., P.-O. Liabot, T. Perrot, N. Radiarta, E. Deslandes, N. Bourgougnon, N. Rossi and V. Stiger-Pouvreau. 2017. In situ evolution of carrageenan content and biomass estimation by satellite image processing for the red macroalgae Kappaphycus alvarezii cultivated in Malasoro Bay, Indonesia. J. Appl. Phycol. 29: 2307-2321.

Setyawidati, N.A.R., A.H. Kaimiuddin, P. Wati, M. Helmi, I. Widowati, N. Rossi, P.O. Liabot and V. Stiger-Pouvreau. 2018a. Percentage cover, biomass, distribution, and potential habitat mapping of natural macroalgae, based on high-resolution satellite data and in situ monitoring, at Libukang Island, Malasoro Bay, Indonesia. J. Appl. Phycol. 30: 159-171.

Setyawidati, N.A.R., M. Puspita, A.H. Kaimuddin, I. Widowati, E. Deslandes, N. Bourgougnon and V. Stiger-Pouvreau. 2018b. Seasonal biomass and alginate stock assessment of three abundant genera of brown macroalgae using multispectral high resolution satellite remote sensing: a case study at Ekas Bay (Lombok, Indonesia). Mar. Poll. Bull. 131(Part B): 40-48.

Shrivastav, A., S.K. Mishra, B. Shethia, I. Pancha, D. Jain and S. Mishra. 2010. Isolation of promising bacterial strains from soil and marine environment for polyhydroxyalkanoates (PHAs) production utilizing Jatropha biodiesel byproduct. Int. J. Biol. Macromol. 47: 283-287.

Sissini, M.N., M.B.B. de Barros Barreto, M.T.M. Széchy, M. Bouças de Lucena, M. Cabral Oliveira, J. Gower, G. Liu, E. de Oliveira Bastos, D. Milstein, F. Gusmão, J.E. Martinelli-Filho, C. AlvesLima, P. Colepicolo, G. Ameka, K. de Graft-Johnson, L. Gouvea, B. Torrano-Silva, F. Nauer, J.M. de Castro Nunes, J. Bonomi Barufi, L. Rörig, R. Riosmena-Rodríguez, T.J. Mello, L. Veras Costa Lotufo and P.A. Horta. 2017. The floating Sargassum (Phaeophyceae) of the South Atlantic Ocean - likely Scenarios. Phycologia 56: 321-328.

Smetacek, V. and A. Zingone. 2013. Green and golden seaweed tides on the rise. Nature 504: 84-88.

South, G.R. 1993. Edible seaweeds of Fiji: an ethnobotanical study. Bot. Mar. 36: 335-349.

Spalding, M.D. 2001. World atlas of coral reefs. University of California Press. pp. 424.

Steneck, R.S. and M.N. Dethier. 1994. A functional group approach to the structure of algal-dominated communities. Oikos 69: 476-49.

Stengel, D.B., S. Connan and Z.A. Popper. 2011. Algal chemodiversity and bioactivity: sources of natural variability and implications for commercial application. Biotechnol. Adv. 29: 483-501.

Stiger, V. and C.E. Payri. 1999a. Spatial and seasonal variations in the biological characteristics of two invasive brown algae, Turbinaria ornata (Turner) J. Agardh and Sargassum mangarevense (Grunow) Setchell (Sargassaceae, Fucales) spreading on the reefs of Tahiti (French Polynesia). Bot. Mar. 42: 295-306.

Stiger, V. and C.E. Payri. 1999b. Spatial and temporal patterns of settlement of the brown macroalgae, Turbinaria ornata and Sargassum mangarevense in a coral reef on Tahiti. Mar. Ecol. Prog. Ser. 191: 91-100.

Stiger, V. and C.E. Payri. 2005. Natural settlement of a young population of Turbinaria ornata and phenological comparisons with older populations. Aquatic Botany 81: 225-243.

Stiger, V., E. Deslandes and C.E. Payri. 2004. Phenolic contents of two brown algae, Turbinaria ornata and Sargassum mangarevense on Tahiti (French Polynesia): interspecific, ontogenic and spatio-temporal variations. Bot. Mar. 47: 402-409. 
Stiger-Pouvreau, V. and F. Guérard. 2018. Bio-inspired molecules extracted from marine macroalgae: a new generation of active ingredients for cosmetics and human health. In: (S. La Barre and S.S. Bates, eds) Blue biotechnology: production and use of marine molecules, part 2: marine molecules for disease treatment/prevention and for biological research. (C) 2018 Wiley-VCH Verlag GmbH \& Co. KGaA. pp. 709-746. https://doi. org/10.1002/9783527801718.ch22.

Stiger-Pouvreau, V., C. Jégou, S. Cérantola, F. Guérard and K. Le Lann. 2014. Phlorotannins in Sargassaceae species from Brittany (France): interesting molecules for ecophysiological and valorisation purposes. Adv. Bot. Res. 71: 379-412.

Stiger-Pouvreau, V., N. Bourgougnon and E. Deslandes. 2016. Chapter 8. Carbohydrates from seaweeds. In: (J. Fleurence and I. Levine, eds) Seaweed in Health and Disease Prevention. Elsevier. pp. 223-274.

Surget, G., K. Le Lann, G. Delebecq, N. Kervarec, A. Donval, M.-A. Poullaouec, I. Bihannic, N. Poupart and V. Stiger-Pouvreau. 2017. Seasonal phenology and metabolomic of the introduced red macroalga Gracilaria vermiculophylla, monitored in the Bay of Brest (France). J. Appl. Phycol. 29: 2651-2666.

Tejada, S., X. Capó, M. Martorell, A. Box and A. Sureda. 2016. Caulerpenyne from the genus Caulerpa: biological and clinical effects. Environ. Res. J. 10: 357-371.

Thabard, M., O. Gros, C. Hellio and J.-P. Maréchal. 2011. Sargassum polyceratium (Phaeophyceae, Fucaceae) surface molecule activity towards fouling organisms and embryonic development of benthic species. Bot. Mar. 54: 147-157.

Thibaut, T. 2017. SARGASSES http://dx.doi.org/10.18142/246.

Torres, M.D., S. Kraan and H. Dominguez. 2019. Seaweed biorefinery. Rev. Environ. Sci. Biotechnol. 18: 335-388.

Trono, G.C. 1999. Diversity of the seaweed flora of the Philippines and its utilization. Hydrobiologia 399: 1-6.

Verbruggen, H. 2014. Morphological complexity, plasticity, and species diagnosability in the application of old species names in DNA-based taxonomies. J. Phycol. 50: 26-31.

Vidal, J.P., D. Laurent, S.A. Kabore, E. Rechencq, M. Boucard, J.P. Girard, R. Escale and J.C. Rossi. 1984. Caulerpin, caulerpicin, Caulerpa scalpelliformis: comparative acute toxicity study. Bot. Mar. 27: 533-538.

Vieira, C., S. D'hondt, O. De Clerck and C.E. Payri. 2014. Toward an inordinate fondness for stars, beetles and Lobophora? Species diversity of the genus Lobophora (Dictyotales, Phaeophyceae) in New Caledonia. J. Phycol. 50: 1101-1119.

Vieira, C., J. Gaubert, O. De Clerck, C. Payri, G. Culioli and O.P. Thomas. 2017. Biological activities associated to the chemodiversity of the brown algae belonging to genus Lobophora (Dictyotales, Phaeophyceae). Phytochem. Rev. 16: 1-17.

Wang, M. and C. Hu. 2016. Mapping and quantifying Sargassum distribution and coverage in the Central West Atlantic using MODIS observations. Rem. Sensing Env. 183: 350-367.

Wells, M.L., P. Potin, J.S. Craigie, J.A. Raven, S.S. Merchant, K.E. Helliwell, A.G. Smith, M.E. Camire and S.H. Brawley. 2017. Algae as nutritional and functional food sources: revisiting our understanding. J. Appl. Phycol. 29: 949-982.

White, W.L. and P. Wilson. 2015. Chapter 2. World seaweed utilization. In: (B.K. Tiwari and D.J. Troy, eds) Seaweed Sustainability - Food and Non-Food Applications. pp. 7-25.
Wijesinghe, W.A.J.P., Y. Athukorala and Y.J. Jeon. 2011. Effect of anticoagulative sulfated polysaccharide purified from enzyme assistant extract of a brown seaweed Ecklonia cava on Wistar rats. Carbohydr. Polym. 86: 917-921.

Wynne, M.J. 2002. Turbinaria foliosa sp. nov. (Fucales, Phaeophyceae) from the Sultanate of Oman, with a census of currently recognized species in the genus Turbinaria. Phycol. Res. 50: 283-293.

Yan, X., Y. Chuda, M. Suzuki and T. Nagata. 1999. Fucoxanthin as the major antioxidant in Hijikia fusiformis, a common edible seaweed. Biosci., Biotechnol. Biochem. 63: 605-607.

Zubia, M. 2003. The industrial valorisation of the invasive brown algae (Fucales) of French Polynesia-Prospective study to fight against their growth and contribute to a lasting management of the coral reef environment. PhD Dissertation, University of French Polynesia. pp 359.

Zubia, M. and L. Mattio. 2019. Macroalgues tropicales: une ressource durable d'avenir. Techniques de l'ingénieur BIO 9040.

Zubia, M., C.E. Payri, E. Deslandes and J. Guezennec. 2003. Chemical composition of attached and drift specimens of Sargassum mangarevense and Turbinaria ornata (Phaeophyta: Fucales) from Tahiti, French Polynesia. Bot. Mar. 46: 562-571.

Zubia, M., D. Robledo and Y. Freile-Pelegrin. 2007. Antioxidant activities in tropical marine macroalgae from the Yucatan Peninsula, Mexico. J. Appl. Phycol. 19: 449-458.

Zubia, M., C. Payri and E. Deslandes. 2008. Alginate, mannitol, phenolic compounds and biological activities of two rangeextending brown algae, Sargassum mangarevense and Turbinaria ornata (Phaeophyta: Fucales), from Tahiti (French Polynesia). J. Appl. Phycol. 20: 1033-1043.

Zubia, M., M.-S. Fabre, V. Kerjean, K. Le Lann, V. Stiger-Pouvreau, M. Fauchon and E. Deslandes. 2009. Antioxidant and antitumoral activities of some Phaeophyta from Brittany coasts. Food Chem. 116: 693-701.

Zubia, M., Y. Freile-Pelegrín and D. Robledo. 2014. Photosynthesis, pigment composition and antioxidant defences in the red alga Gracilariopsis tenuifrons (Gracilariales, Rhodophyta) under environmental stress. J. Appl. Phycol. 26: 2001-2010.

Zubia, M., M. Depetris, O. Flores, J. Turquet and P. Cuet. 2018. Macroalgae as a tool for assessing the ecological status of coral reefs under the Water Framework Directive: a case study on the reef flats of La Réunion (Indian Ocean). Mar. Poll. Bull. 137: 339-351.

Zubia, M., O.P. Thomas, S. Soulet, M. Demoy-Schneider, S. Saulnier, S. Connan, E.C. Murphy, F. Tintillier, V. Stiger-Pouvreau and S. Petek. 2019. Potential of tropical macroalgae from French Polynesia for biotechnological applications. J. Appl. Phycol. doi.org/10.1007/s10811-019-01920-8.

Article note: This article is part of the special issue series of Botanica Marina: Seaweed resources of the world: a 2020 vision, which has started publication in Botanica Marina 2019, vol. 62, issue 3. The series is guest-edited by Alan T. Critchley, Anicia Hurtado, Leonel Pereira, Melania Cornish, Danilo Largo and Nicholas Paul. 


\section{Bionotes}

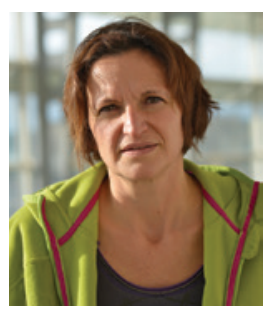

\section{Valérie Stiger-Pouvreau}

Université de Bretagne Occidentale (UBO), CNRS, IRD, Ifremer, UMR-LEMAR, IUEM, rue Dumont d'Urville, 29280 Plouzané, France, e-mail: valerie.stiger@univ-brest.fr
Valérie Stiger-Pouvreau is an associate professor at the University of Brest (UBO) since 2000. She carried out a PhD in French Polynesia, on the invasion of coral reefs by Sargassaceae species. At UBO, she took the Head of a Master's degree in Biology in 2017. Her research topic is about the adaptation of seaweeds face to global change, together with their taxonomy and biotechnological applications. She works on chemical ecology, which leads her to conduct fundamental and applied research with industrial enterprises in France and Europe. https://orcid.org/0000-0003-3041-0468 https://www. scopus.com/authid/detail.uri?authorld=14037920200.

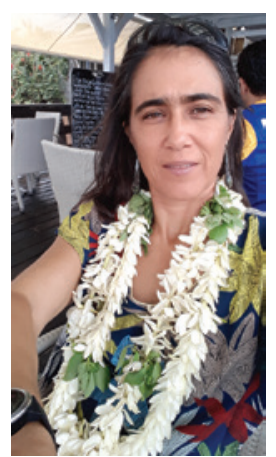

\section{Mayalen Zubia}

University of French Polynesia, UMREIO, BP6570, 98702 Faa’a, Tahiti, French

Polynesia

Mayalen Zubia is a lecturer at the University of French Polynesia since 2013. Her research activities focus on the diversity of tropical marine flora (macroalgae and cyanobacteria) in the Indo-Pacific coral reefs, in using the integrative taxonomy (morphology, genetic, chemical ecology and microbial community) to better understand the variability of floral assemblages under natural and anthropogenic disturbances (overfishing, pollution, disease, ...). In parallel, she's working on numerous applied research projects for the valorization of this algal diversity. https://www.researchgate.net/profile/Mayalen_Zubia. 